\title{
The Temporal and Spatial Structure of Medieval Expulsions of Jews
}

\author{
Kerice Doten-Snitker* \\ Chapman University \\ This version: February 10, 2023
}

\begin{abstract}
What social processes guide the spread of ethnic or racial exclusion? I investigate the diffusion of medieval expulsions of Jews among over 500 polities in the western Holy Roman Empire, 1385-1520 CE. For medieval governors, religious and material concerns were strong rationales against expulsion. Yet expulsions increase markedly in the fifteenth century. Did an expulsion by one government affect another government's choices about expulsion? Using event history analysis methods, I appraise whether theories of policy diffusion explain the limited spread of expulsion. The adoption of expulsion followed political and economic incentives that were embedded in inter-city relationships of power and dependency, particularly after theological changes gave expulsion fresh political value. Interdependence can spur as well as squelch ethnoracial extremism. We should give greater consideration to how social influence shapes the institutionalization of social closure and explore how the diffusion of ethnoracial inclusion or exclusion reimagines general theories of policy diffusion.
\end{abstract}

The bulk of diffusion research follows a pro-innovation bias (Karch et al. 2016) because researchers are interested in how to spread "good" things. Social scientists study these phenomena to understand why positive and pro-social behavior gain support (Braun 2016; Fisher, Yagatich, and Robertson 2017). On the other hand, social scientists want to know how to mitigate the spread of negative or anti-social behavior (Braun and Genkin 2013). Social diffusion processes have eased the spread of racial extremist political parties (Rydgren 2005), fascism (Weyland 2010), and techniques for repression (Olar 2019). Minority-targeted violence can spill over from one community to another (Braun 2011) and from one organization to another

\footnotetext{
* Correspondence may be directed to Kerice Doten-Snitker at dotensni@chapman.edu.

I thank Michael Hechter, Steve Pfaff, Edgar Kiser, Robert Stacey, Yuan Hsiao, Jean-Paul Carvalho, Vesall Nourani, Kate Stovel, Jeff Kopstein, Robert Braun, Juan Fernández, Damon Mayrl, Sarah Valdez, Maureen Eger, Jared Rubin, Chris Bader, Larry Iannaccone, and Anna Grzymala-Busse for developmental comments. I owe a debt of gratitude to Brian Bossak and Mark Welford for generously sharing the data they collected with their students on medieval pilgrimage routes. This paper also benefitted from comments at the following conferences or departments: the Association for the Study of Religion, Economics, and Culture; the IRES Graduate Workshop; the Association for the Sociology of Religion; the Social Science History Association; the London School of Economics Department of Economic History; Umeå University Department of Sociology; and the University of Washington Department of Sociology. Grant Snitker and Claudine Gravel-Miguel provided GIS insight and computations. Nick Gauthier generously shared scripts and know-how on CCSM4.0 climate data. Research support was provided by the Deutsche Akademischer Austauschdienst via a Short Term Study Grant to be a visiting student at the Arye Maimon-Institüt für Geschichte der Juden at Universität Trier. Remaining errors are most certainly my own.
} 
(Tschantret 2019). However, even studies of violence show less contagion than might be assumed (LaFree, Xie, and Matanock 2018).

Though we may be interested in promoting the uptake of pro-social action and scared by the diffusion of harmful action, understanding what constrains behavior or policy adoption deserves just as much attention as what facilitates it. This study focuses on how social influences shape intolerance (Hjerm et al. 2019). There is an extensive literature on the genesis, migration, and brightening of ethnoracial symbolic and social boundaries (Brubaker 2004; Fields and Fields 2014; Hale 2008; Hechter 1987; Lamont 2000; Kroneberg and Wimmer 2012). Theories of institutionalization describe how these boundaries are encoded in governments and laws, as what I draw on Max Weber to term institutionalized social closure (Fiel 2013; Weber 1964; Weeden 2002). Shared boundaries and social orders do not always translate into the same levels of institutionalized social closure.

I ask why exclusionary policies do or do not spread (Tolnay, Deane, and Beck 1996), using the case of expulsions of Jews from cities in the medieval Holy Roman Empire. Expulsions were forced migrations carried out by governments following legislative declarations. They served financial ends, performed Christian duty, and solved political problems (Dorin 2023; Doten-Snitker 2021; Johnson and Koyama 2019; Müller 2002). The constituent polities of the Holy Roman Empire shared a social order that excluded and stigmatized Jews. This hierarchy was strengthened from the late fourteenth and especially the fifteenth century. It was an era of possibility for increased exclusion. Indeed, the number of German expulsions climbed considerably in the fifteenth century (Haverkamp 2002).

I test four theories of social influence with a database of 578 medieval German cities, covering 105 expulsions in the period from 1385 to 1520 . Medieval German lands were dense with semi-autonomous urban governments linked within a political culture without absolutist hierarchies (Hardy 2018). The large number and variety of urban governments creates an opportunity to study a racially extreme policy's diffusion in a much larger group than would be possible for most modern policies. Time-series regression analyses including spatiotemporal lags account for different types of social dependence between cities as well as other city-level factors. Though interpersonal ethnic violence can perhaps be provoked by observing others (Bauer et al. 2018; Jäckle and König 2017), general processes of learning and exposure to new policy ideas were ineffective mechanisms of spreading institutionalized social closure. Structural inequalities 
shaped whose adoption of expulsion mattered to other cities and which city governments opted for expulsion.

In the first section, I explain why expulsion was historically counter-normative for medieval German cities and how the fifteenth century challenged this, including the history of antisemitic expulsions in Europe and how Christian rulers interpreted Jews as their subjects. I also introduce the main data source and rationale for the study's scope. I then outline how different types of social influence could nevertheless initiate policy diffusion among German cities. Next, I describe how I operationalize potential diffusion mechanisms and my statistical method. Following the results, I concentrate on the lessons for broader debates on what explains the diffusion of cultural policies (Go and Watson 2019; Wimmer 2021). Applying ideas from policy diffusion to social closure, in a setting that shares the decentralized political structure of many modern polities, demonstrates how resource distributions produce divergent social (dis)incentives to increase exclusion.

\section{SYMBOLIC BOUNDARIES, JEWS, AND POLICY}

Expulsions of Jews in Western Europe were sporadic before the thirteenth century. Whereas France expelled all Jews off and on and England expelled Jews in 1290, Kaiser Friedrich I (Barbarossa) confirmed his Christian responsibility to protect those who were faithful to the traditions of their fathers ${ }^{1}$ in Iudaeis nostris Ratisponensibus, after the 1182 French expulsion. Generations of German kings followed suit, affirming Jewish rights as part of the spectacle of coronation. In German cities and principalities, Jews made contracts for their protection and gained citizenship rights (Cluse 2009; Haverkamp 1999; Toch 2003; Wenninger 2012), in much the same way as other internal and foreign immigrants (Darman 2009). Although the general norm in medieval Germany was non-expulsion, city governors did have reasons to ignore it, based on what meaning they put on having Jewish residents. Previous research has identified three primary ways Jews might be interpreted as assets within their wider communities: financially, religiously, and politically. Changes to Christians' religious and political interpretations of Jews brought increased institutionalized social closure to Germany.

\footnotetext{
${ }^{1}$ Ancestry has long been connected to understandings of peoplehood in Europe. In medieval Europe, Jewish blood made someone Jewish (Nirenberg 2009), though stereotypical (Weeda 2014) cultural and linguistic behaviors were the evidence of innate Jewishness (Bartlett 2001; Stow 2001). Consult Heng (2018).
} 
The financial view of Jews was that they were a financial asset to be exploited and manipulated to maximize governors' incomes (Levi 1981; Olson 1993), including via contributing to the commercial and fiscal health of polities (Finley and Koyama 2018; Ries 1995; Scholl 2015). Understanding Jews as a financial resource is the dominant explanation in economic history for expulsions (Barzel 1992; Koyama 2010; Stacey 1997; Wenninger 1981). There were long-term benefits to maintaining a Jewish community. Religious difference enabled governors to develop financially exploitative policies (Johnson and Koyama 2019) that larger and more powerful Christian populations could effectively rebel against, such as permission from the German emperor to levy special taxes on Jews. In the short term, governors might confiscate Jews' properties and other assets. Further, if a polity expelled its Jewish residents, a nearby authority might offer Jews residency to bolster their own finances. The Bishop of Metz did exactly this after the Archbishop of Trier expelled Jews from his territories in 1418 (Haverkamp 1999). If anything, there was demand for Jewish residents, and competition over who held the rights over their residency and taxes.

A second way Christian governors interpreted the presence of Jews in their cities was that Jews were an asset for Christian social order. Christianity-influenced beliefs declared that a good community included Jews because a) God had made a covenant with them, and thus they were the forebearers and partial inheritors of the promised apocalyptic Kingdom of God, and b) they were an example and contrast for Christians, who should behave more righteously than Jews (Battenberg 1987; Stacey 1992; Stow 1992). Thus popes proclaimed that the Church protected Jewish practice by Jews (Stow 2007). However, theological innovators began to conceive of the relationship with Jews as a moral threat for Christians (Luzzati 1999). This reformulation was taken up at the Council of Constance, which met 1414-1418 in Constance in modern southern Germany to unify Christendom against heterodoxy (Grayzel 1967, 302-4; Housley 2017). A new crusade against the Hussite sect and heretics in Europe was announced with a simultaneous call for all Christian rulers to exercise Christian dominion through orthodox purity in belief and behavior (Blickle 1992; Housley 2017; M. Rubin 1999). From the fifteenth century the canonical ban on usury was applied also to Jews (Dorin 2015; 2016), and church reform in the fifteenth century made Jewish financial activities a frequent reason for expulsion (Cluse 1999). This change in meaning was consequential. 
A third meaning for Christian governors was that resident Jews were a political asset. For one thing, Jews were convenient scapegoats. They were blamed for disturbances or social problems, from pandemics to economic crises (Anderson, Johnson, and Koyama 2017; Barkey and Katznelson 2011; Cluse and Müller 2009; Haverkamp 2004; Jedwab, Johnson, and Koyama 2019). Mistreatment by the government, including imprisonment and execution, could mollify an agitated Christian population by demonstrating that governors were taking action to address popular concerns. Performative antisemitism during Christian holy times (Nirenberg 1996) demonstrated city leaders' Christian bona fides and deservingness as governors. Governors distanced themselves from the burdens of their government via policies that raised taxes on Jews, who then had to pass along increased costs of business to their mostly middle- and lower-class customers (Gilomen 2009). Because Jews became intermediaries, and because rights to "protect"2 (and therefore tax) them was farmed out, there was a nesting doll-quality for maintaining or expelling a Jewish community. City governors who lacked legal and economic control over the local Jews might expel the Jews to dodge indirect taxation and intervention in their affairs by another political elite.

These three ways of interpreting the symbolic boundary between Jews and Christians led to the status quo of non-expulsion in German lands, which could be selectively reinforced by economic and political sanctions. Punishments were in service of the peace of the land because expulsion was disruptive to the broader political and economic community. Expulsion might attract punishment via fines or siege by the Holy Roman Emperor (M. Rubin 1995), to whom Jews ultimately legally belonged. But the German empire was not especially hierarchical and functioned more as a collection of fluctuating associations, sometimes formal and sometimes not, between governments and elites of varying size and clout (Hardy 2018). Regional political alliances (Bünde) (Distler 2006) included directives about protecting Jews based in the fear that an uprising within a city, which might expel or murder Jews, would spread to other cities (Scholl 2012), and Bünde, too, occasionally assessed fines as well as suspended members for violence against Jews (Hagen 2018). Economically, expelling Jews interrupted local commerce, both because a portion of the local economy disappeared and because Jewish moneylenders closing

\footnotetext{
2 "Protecting" (translated from Sicherung or Schutz) Jews meant little more than exercising mastership over them. As a legal concept, it included responsibilities, but more importantly it included rights.
} 
shop meant that necessary access to credit was restricted (Botticini 2000; Gilomen 2009). But social reinforcement was incomplete, and expulsions did increase.

I draw my observations of cities and their expulsions from Geschichte der Juden im Mittelalter von der Nordsee bis zu den Südalpen [The History of Jews in the Middle Ages from the North Sea to the Southern Alps] (Haverkamp 2002). This source covers the Rhineland and environs for the period 1000CE-1520 CE. Unlike Encyclopedia Judaica, the other historical catalog of European Jewish communities, it covers all cities with Jewish residents, from the smallest to the biggest, within its geographical scope. The selection bias in Encyclopedia Judaica would be a poor foundation for studying diffusion.

Expulsions could be enforced for territories or individual cities. I measure the occurrence of an expulsion at the city level and refer to these expulsions as local expulsions. I localize territorial expulsions by coding their occurrence in the city that is the territorial prince's residence. I code each city as having no expulsion (0) or a local expulsion (1) in a year.

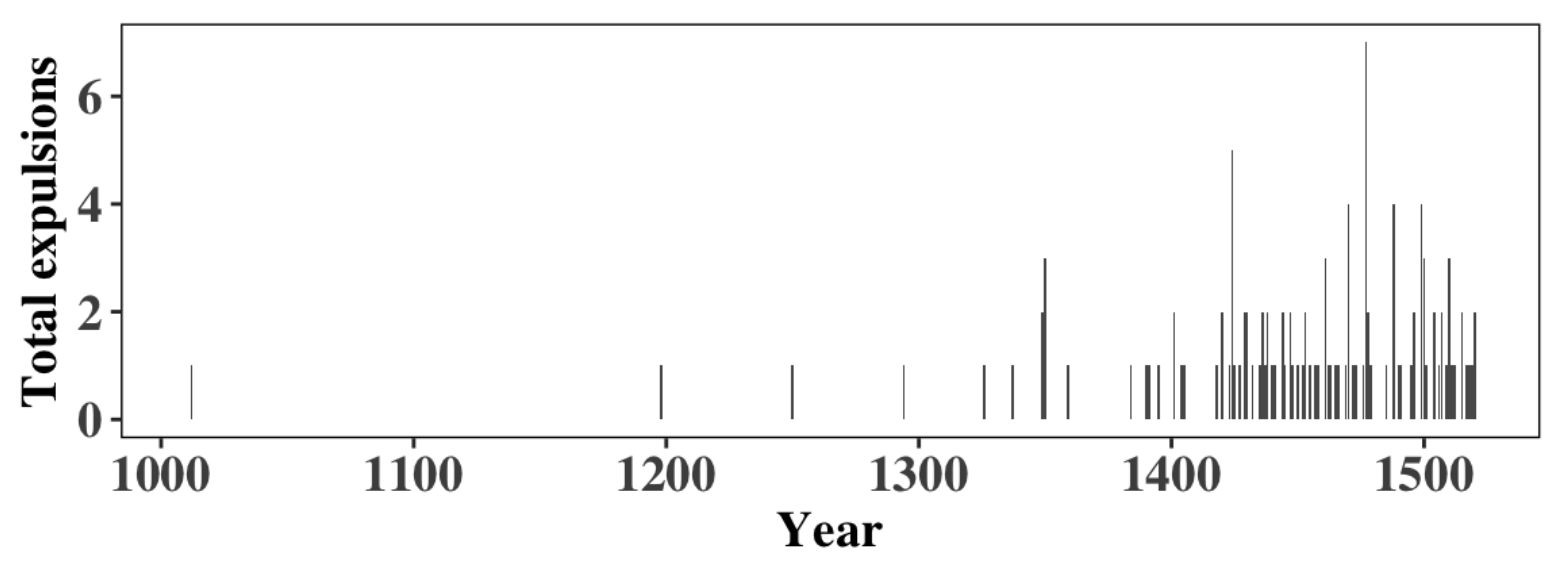

Figure 1. Expulsions of Jews from German Cities, 1000-1520 CE 


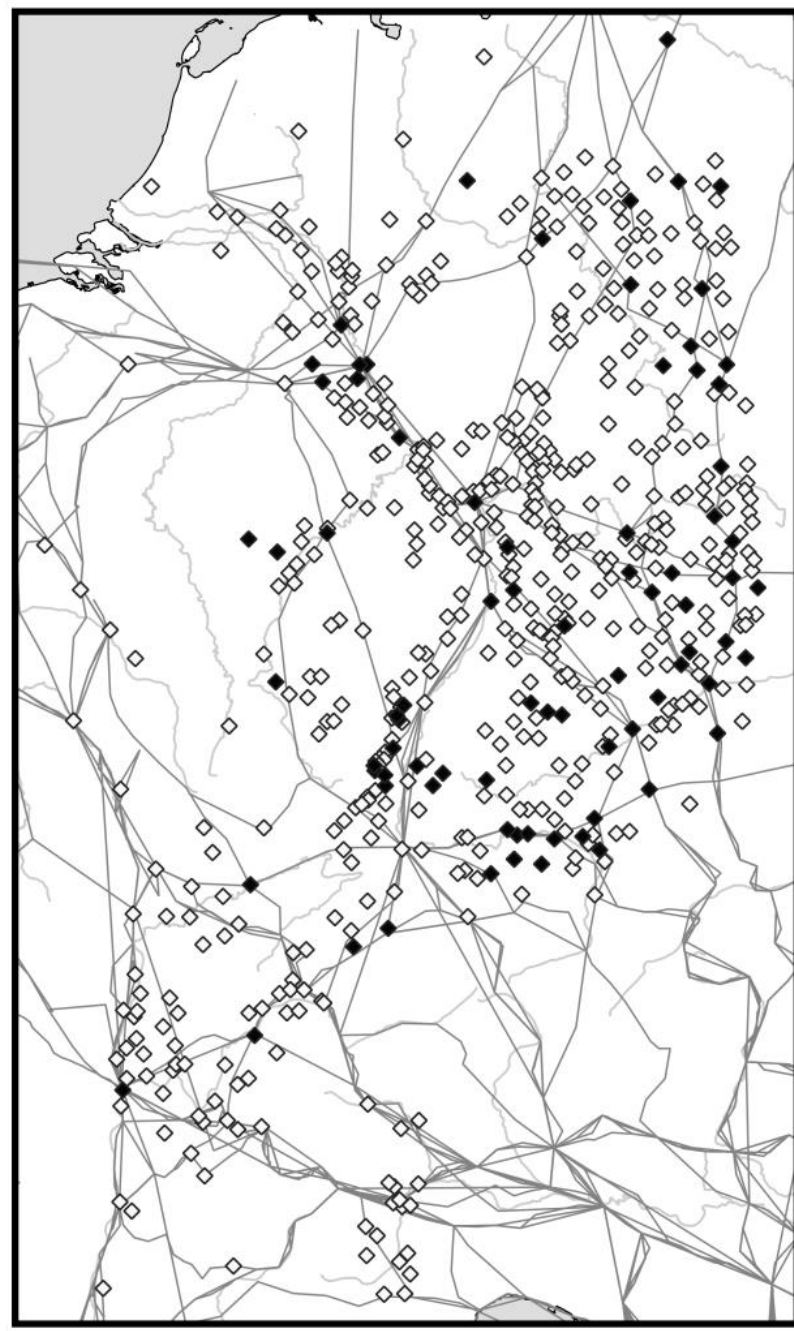

Approximate study area, with modern cities

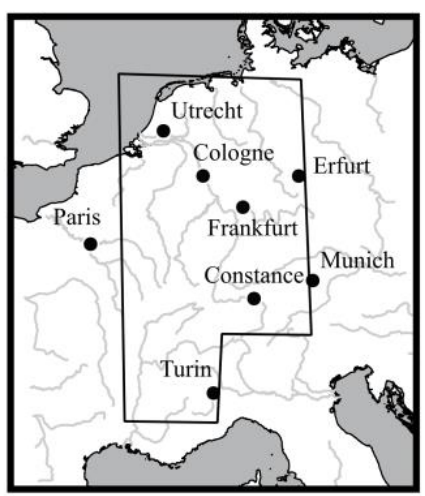

$\diamond$ Cities that did not expel their Jewish residents

- Cities that expelled their Jewish residents

- Pilgrimage routes

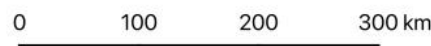

Figure 2. Jewish Settlement and Expulsions in the Western Holy Roman Empire, 1385-1520 CE, with Travel Routes (Pilgrimage and River Networks)

Looking at the trend for the number of expulsions per year, seen in figure 1, the number is sporadic before the fifteenth century. The ideological and legal foundations for expulsions of Jews were yet to be established. I elect to limit the temporal scope of these analyses to 1385 $1520 \mathrm{CE}$ for historical and methodological reasons. The first notable expulsion was in 1390 from the Prince-Electorate of Pfalz (Maimon, Breuer, and Guggenheim 1987). The institution of the first Judenschuldentilgung, an empire-wide transfer of debts to Jews to cities and King Wenceslaus, in 1385 would be a potential hinge in the political and economic interpretation of Jewish residents (Hagen 2018, 229). Methodologically, choosing 1385 as a starting year includes 
ample time and observations to detect temporal dependencies. Figure 2 maps the geographic distribution of cities where Jews lived during this period and cities that expelled Jews. Within this region, Jews lived in 578 cities, and they were victims of 105 local expulsions. Expulsions were a persistent but still unusual occurrence. How did social influence facilitate or constrain the implementation of expulsions?

\section{THE ROLE OF SOCIAL INFLUENCE IN EXCLUSIONARY POLICY}

Policy decisions are a product of both domestic and external factors (Myers 2000; Shipan and Volden 2008). By external factors, I mean the social structures and relationships that influence governors' ${ }^{3}$ choices (Burt 1987; Strang 1991). There are two ways to think about social influence. The first, what successfully propagates new behavior?, is the most common within the significant literature on policy diffusion (Dobbin, Simmons, and Garrett 2007; Gilardi and Wasserfallen 2019). The second way of thinking about social influence, what constrains and prevents new behavior from spreading? (Clemens and Cook 1999; Darwich 2017), is a useful reframing, especially with a corollary what constraints fail when a new behavior is propagated? In particular, this corollary draws our attention to the fact that social influence works to uphold some actions that might compete with deviations (Hsiao 2022). While some types of actions might truly open new frontiers, new policies are among those that, when introduced, are not free to spread in some tabula rasa-type situation but rather are at a disadvantage compared to widely adopted existing policies. There are two phenomena at issue: the predominance of the status quo plus a fraction that diverges to expel. To understand the uptick in expulsions, we must think about when social influence supported the anti-expulsion norm, when it moderated the norm, and when the domestic incentives to transgress were magnified. Potential factors include exposure to others' expulsions, technical learning, the development of new social meaning, and social structural and resource constraints.

Exposure

Social ecosystems channel information about and the social meaning of a policy. Social structure can facilitate awareness of another policy at the same time as it can isolate from

\footnotetext{
3 Throughout I use "governors" to refer to the people governing polities. While "governor" can be a specific office in some political systems, here it is more generic, and encompasses governments of individual nobility as well as deliberative bodies or councils, than calling all such governing people "rulers".
} 
exposure to policy trends happening elsewhere (Centola 2015; 2018). Generically, we might expect that cities expelled Jews after other cities did so. But city governors needed to learn about these other expulsions somehow. Information networks carry details about why new behaviors and ideas are attractive or unattractive. Information networks were highly correlated with transit routes. Interpersonal contacts along travel routes have been a determinant in the spread of political movements (Aidt, Leon-Ablan, and Satchell 2022; Brooke and Ketchley 2018). In the medieval world, information traveled via letters and travelers (Becker et al. 2020). Transit networks that carried letters, people, and regular commercial exchange are a hybrid of geographic and social structure. Information about expulsion surely moved unevenly in German lands, and so perhaps expulsion was adopted unevenly based on the flow of information about expulsions elsewhere.

\section{Technical learning}

Governors might adopt a policy or not based on technical learning (Gilardi and Radaelli 2012; Shipan and Volden 2008; Volden, Ting, and Carpenter 2008). Especially when a political behavior is relatively untested or materially risky (Olar 2019), political actors might value reassurance from observing others they perceive to face similar institutional realities (Greve, Kim, and Teh 2016; Horowitz 2010; Linebarger 2016). Gilardi, Shipan, and Wüest (2021) find that interpreting a new policy as technologically efficacious prompts the diffusion of the policy. I already noted that politically prominent cities were in regular communication to coordinate their affairs, which they formalized in Bund treaties. Most of the alliances were concluded prior to the fifteenth century (Distler 2006), though these cities remained peers in other ways. Prior Bund relationships would be the most likely to share this technical policy information, given their history. However, in this case, expulsion was not a new technology; expulsions had been occurring in Europe in previous centuries, including a few within the Holy Roman Empire. The technological meaning of Jews, that they were a tool for government finance, was settled. New social meaning

Another possibility is that expulsion spread because it was imbued with new social meaning (Bail, Brown, and Wimmer 2019; Koenig and Dierkes 2011; Sikkink 2014). Who else does it first tells city governors something about why they should expel, beyond the material meaning. When we consider doing something new that we know has significant drawbacks, we sometimes look to our closest friends and neighbors (Hadden and Jasny 2019) or to thought 
leaders (DeMora, Collingwood, and Ninci 2019; Watts and Dodds 2007), whose adoption of a new behavior gives social desirability or credibility to it (Abrutyn, Mueller, and Osborne 2019; Brown 2019; Strang and Macy 2001). Therefore, we would expect that cities expelled Jews after prestigious cities did so first. Similarly, a shift in the Christian religious meaning of Jews that rejected their co-residence in European Christendom could prompt a sea-change. The Council of Constance and subsequent anti-heresy crusade in Europe gave expulsion not only new religious meaning but new political meaning. This change both incentivized expulsion and diminished the threat of sanctions for it. Thus, we might expect that expulsions increased particularly after 1418, and perhaps also most of all nearer to Constance, as news spread and Council attendees returned to their cities. Other fifteenth- and sixteenth-century social changes likewise appear to have radiated from their epicenters (Cantoni 2012; Dittmar 2011; J. Rubin 2014). It also seems plausible that religious cities like the seats of bishops and archbishops would adopt expulsion after the Council of Constance. Conversely, if prestigious cities or religious governors did not expel Jews, then other cities might hesitate to change in order not to lose esteem and be socially associated with less-desirable or less-prestigious political players (Bail, Brown, and Wimmer 2019).

Expulsion might become a process of isomorphism, a specific class of imitation when a particular policy is perceived as more legitimate and standard-setting (Clemens and Cook 1999; DiMaggio and Powell 1983; Meyer et al. 1997), without respect to material incentives. Expulsion had a few traveling evangelists in the form of traveling clerics like Nicholas of Cusa, whose preaching was tied to the 1445 expulsion from Eichstätt (Maimon, Breuer, and Guggenheim 1987). Isomorphism might look like expulsions increasing among diverse cities after a few notable ones, the adoption of a new form in the expectation that this model, a city without Jews, was the universal model for legitimate governance. But if standard-setting governors do not change policy but instead stick to some status quo, others might be loath to step out of compliance.

\section{Structure and resource distributions}

Social structure itself might also be important for the spread or containment of expulsion (Centola 2015; Reagans and McEvily 2003; Watts and Strogatz 1998). Governors of structurally equivalent polities share conditions produced by political economy and social structure. Where those shared conditions are relevant, governors in equivalent positions might switch policies, or 
indeed hold on while others change tacks (Centola 2015). With the new political meaning, expulsion sent a challenge to the imperial political system (Evers 2017) that privileged the major noble families. Relationships among autonomy-seeking cities, united in their political structural equivalence, might propagate this new political meaning as well as confer reassurance and a sense of belonging or identity (Acharya 2011; Meyer et al. 1997) about transgressing. If this occurred, we should observe that autonomous cities were more likely to expel, and that expulsions by autonomous cities spurred other cities to expel. Pragmatically, the potential costs of rebellion were diminished (Dixon and Roscigno 2003) as powerful peers expelled first, and they might even provide martial support against military intervention by the emperor.

Relatedly, resource interdependencies across polities of differing structural positions might incentivize certain policy choices over others (Jones and Zeitz 2019; Kim, McDonald, and Lee 2018). There can be resource consequences for being in alignment, or not, with the policies of a polity you depend on. The regional political economy functioned as a network of urban hubs plus their hinterlands (Eiden and Irsigler 2000; Sassen 2006; 2014; Snyder and Kick 1979), providing spatial structure to economic and social relations. Thus the economic and political incentives to expel, as well as tolerance to the disincentives, were spatially distributed. More economically stable autonomous cities (Chilosi and Volckart 2011) were nearby to smaller, less developed cities, who had greater economic interest in preserving Jewish communities and political aversion (as well as reduced agency) to commit a political transgression. Expulsion might actually relocate Jews to smaller places where they were under more direct control of territorial lords who held rights over them, as happened in Cologne in 1424 when the city expelled its Jews, who were technically under the dominion of the Archbishop of Cologne (Wenninger 1981). The interaction of the political meaning of expulsion with economic incentives could produce a bull's-eye pattern of expulsions in prominent cities surrounded by cities that do not expel. In this way resource interdependencies would diminish the power of constraints to policy change for some governments while preserving them for others.

An additional layer of complication, both for political decision-makers and for researchers attempting to track what facilitated or spread a policy idea, is that none of these processes are particularly mutually exclusive. They can occur simultaneously, or successively, and the task for the observer becomes a difficult question of ascertaining the motivations of others, and whether they are consistent with what would make you, a governor, stick with a 
policy or else jump ship. Wimmer (2021) describes this quality of some policy adoption processes as polysemy; they can be interpreted or argued for using different logics. Wimmer hypothesizes that polysemy contributes to the uptake of an action. Semantic noisiness can allow for multiple mechanisms of diffusion, drawing in adopters who respond to different types of incentives or cues. This is one reason why examination of the same diffusion process using different theories can lead to different conclusions. However, multiple meanings can also render a policy illegible. The noisiness of a policy has as much possibility to impede diffusion as it does to facilitate it. The inertial power of polysemy might be evidenced by limited empirical relationships between expulsions, both in the statistical sense and when descriptively considering the temporal and categorical patterns.

\section{MEASUREMENT AND METHODOLOGY}

Measuring this phenomenon requires data on Jewish settlement and expulsions for a large proportion of the political units in medieval Europe where Jews lived. I translated and digitized the gazetteer from Geschichte der Juden im Mittelalter von der Nordsee bis zu den Südalpen (Haverkamp 2002). Then I recoded and reorganized the data from half-century period-based observations into annual observations of each city. Cities are included only for years of certain Jewish presence. More information about this source, as well as data collection and coding decisions, can be found in Appendix A.

Diffusion

In order to account for processes of exposure, scholars often expand the window of how long we expect it to take for some behavior to be adopted. Hedström (1994), Andrews and Biggs (2006), and Braun (2011) use the count of events $N$ in the polities $j$ (which is the sample excluding city $i$ ) in the previous time period as a general contagion measure. I have calculated this for my dataset for a range of period lengths. The main results use a 10-year lag (see table 1 for descriptive statistics).

$$
\operatorname{Dif} 1_{i}=\sum_{t-10}^{t-1} N_{j}
$$

To measure access to networks that might spread exposure to expulsion, I include the count of roads and rivers passing through a city, sourced from the late medieval pilgrimage road network compiled by Bossak and Welford (2015) and the network of European rivers in Natural 
Earth II (version 4.1.0), calculated using the R package raster (Hijmans 2019) and a $5 \mathrm{~km}$ threshold. The count of travel routes proxies for a network centrality score. ${ }^{4}$ Most cities were on at least one travel route; some were on as many is 13 routes.

Political associations might have transmitted technical information about the value of expulsion as a policy. For each city, I calculate the cumulative count of Bund agreements a city had concluded in prior years, based on Distler's (2006) list of Bünde and their city signatories. Of 578 cities, 78 were party to treaties; 41 signed treaties during the period under study.

Historical research suggests that the Council of Constance shifted religious and political perceptions of Jewish subjects. A dummy variable contrasts observations before and after 1418 . To measure the spatial relationship to Constance, I calculated least-cost paths along the travel routes. After some preprocessing in QGIS (see supplementary materials), the network distances to Constance in kilometers were obtained through the riverdist R package (Tyers 2017). Because the city catalog of Geschichte der Juden lists details about city political and economic histories, I can assess whether expulsions spread after the Council of Constance within religiously-governed cities or among autonomy-seeking cities. I coded city dominion, who held rights of rule in the city, on an annual basis. I measure whether dominion included an archbishop or bishop, whether a city was the seat of an archbishopric or bishopric, which cities were "free" and formally held rights of self-government, and which cities were imperial cities that were under the direct authority of the Holy Roman Emperor.

Above I argued that the incentives to expel were not evenly spatially distributed, and I offered a few reasons why expulsions might be spatially isolated. I calculated least-cost paths along transit routes between all cities. Following Braun (2011) and Hedström (1994), for each year I summed the distances to expulsions $D_{i j}$, then took the square root. I inverted this and multiplied by the number of expulsions, after which I summed in ten-year moving windows, to calculate Dif 2 , a spatiotemporal lag (Beck, Gleditsch, and Beardsley 2006). To directly assess whether expulsions compounded among categorical groups, or whether expulsions among particular groups spurred expulsions more broadly, I modify Hedström's equation. The count of expulsions $N$ can be restricted to those in a group $G$ across a sample in the previous time period.

\footnotetext{
${ }^{4}$ Becker, Hsiao, Pfaff, and Rubin (2020) reconstructed a city network across a similar geographic scope for the sixteenth century, with 120 cities in common (20\% of cities in this study). Of the 105 expulsions, 44 could not be matched to cities in the Becker et al. sample. These 120 cities are not an unbiased sample of the overall city network; unmatched cities in this study's sample were much more likely not to be within $5 \mathrm{~km}$ of a road or river.
} 
I calculate three versions of Dif2: among episcopal cities (ruled by a bishop or archbishop), among free or imperial cities, and generically among all cities. Values increase with closer expulsions $^{5}$ or with a greater number of expulsions in the previous years at a consistent distance.

$$
\operatorname{Dif} 2_{i}=\sum_{\substack{t-10 \\ j \in G}}^{t-1} \frac{N_{j}}{\sqrt{D_{i j}}}
$$

Returning to the temporal lag, I also create Dif $3_{i}$ by again restricting to those in a group $G$, as with $D i f 2_{i}$. In parallel with $D i f 2_{i}$, I do this for prior expulsions among episcopal and among free or imperial cities.

$$
D i f 3_{i}=\sum_{\substack{t-10 \\ j \in G}}^{t-1} N_{j}
$$

When Dif2 and Dif3 are included in a model, the model assesses whether certain groups of cities were thought leaders or led an isomorphic process such that expulsions in that group contributed to the occurrence of expulsions in other cities, irrespective of those cities' position within the imperial political structure. Including a binary interaction for group membership alongside the group restriction works in an adjacency matrix based in social structure, testing whether the group-specific trend has an impact among peer cities.

Table 1. Descriptive Statistics: Diffusion measures

\begin{tabular}{llllll}
\hline & Min & Max & Mean & Median & St. Dev. \\
\hline Expulsion & 0 & 1 & 0.003 & 0 & 0.05 \\
Year & 1385 & 1520 & 1444.29 & 1441 & 35.70 \\
Prior alliance treaties & 0 & 20 & 0.91 & 0 & 2.80 \\
Route Count & 0 & 13 & 1.27 & 0 & 2.14 \\
After Council of Constance & 0 & 1 & 0.73 & 1 & 0.45 \\
Distance to Constance & 0 & 954.57 & 356.48 & 356.68 & 155.62 \\
Dif1: Any expulsions & 0 & 17 & 6.97 & 8 & 3.85 \\
Dif2: Only in episcopal cities & 0 & 1.10 & 0.05 & 0 & 0.11 \\
Dif2: Only in free or imperial cities & 0 & 4.92 & 0.06 & 0 & 0.25 \\
Dif2: Any expulsions & 0 & 10.76 & 0.96 & 0.74 & 0.99 \\
Dif3: Only in episcopal cities & 0 & 1.10 & 0.05 & 0 & 0.11
\end{tabular}

\footnotetext{
${ }^{5}$ Recent expulsions in the same city $i$ are dropped because their distance is $0 \mathrm{~km}$. The importance of prior expulsions in city $i$ will be measured directly.
} 
Commonly, social influence is measured directly through some sort of observed social tie, either focusing on structural position or else relationships among network members. In this case, social network reconstruction beyond categorical assignments is fraught and would introduce more problems than it solved. Any spatial-structural network measures calculated using the sample in this study would be hampered by structurally missing cities; many other cities existed but did not have Jews. Therefore the cities here might appear spatially adjacent, but this was not necessarily the case. Similarly, these cities are only part of the political and economic networks of the time. The diffusion measures should be calculated in reference to factors unassociated with the incompleteness of the sample, in terms of its representativeness of the broader historical context. In this case, physical distance is the better measure than binary spatial adjacency, and the social adjacency of equal-status ruling parties can still be accounted for through group-based measures, akin to a block model (White 1965).

\section{City-level variables}

The city-level political economic incentives for and against expulsion are not the main focus of this paper. Anderson, Johnson, and Koyama (2017), Doten-Snitker (2021), and Finley and Koyama (2018) have investigated domestic incentives for adopting the policy of expulsion. Here, I include city-level factors from these prior studies, again coded from the city catalog in Geschichte der Juden. These include political institutions, economic development and institutions, and Christian and Jewish religious development. Descriptive statistics are in table 2. Additionally, time is included as a categorical effect through 15-year dummies, which splits the period into nine equal categories that do not overlap with any of the temporal variables.

I operationalize political authority in several ways. Besides the binary categorizations for religious rule and autonomy, I also code whether dominion rights were held by a prince. A city might be under the dominion of several types of governors; I measure the potential for political competition and volatility as the count of authorities over a city. I include the presence (1) or absence (0) of Schöffen as a governing body in the city. A college of Schöffen was a quasi-legal body (Isenmann 2012) charged with maintaining public order (Börner 2010).

Domestic economic incentives for and against expulsion center on a city's economic opportunities and how city authorities could collect funds. A general metric for economic 
development was commercial development, and I construct an ordinal measure of market activity (no markets (0), one market or a generic record of market rights (1), multiple markets (2), any number of fairs (3)). To capture the impact of alternative financial resources to confiscation from or exploitation of Jewish communities, I include the presence (1) or absence (0) of foreign merchants and rights to mint coins.

Finally, I measure aspects of communal religious life. I construct a cumulative index of Jewish community infrastructure, counting how many types of infrastructure a Jewish community had (synagogue, cemetery, mikveh, Jewish quarter) on a scale from 0 to 4 . To approximate the local inter-religious history, I measure the incidence of both prior expulsions and prior persecutions in a city.

Table 2. Descriptive Statistics: City characteristics

\begin{tabular}{llllll}
\hline & Min & Max & Mean & Median & St. Dev. \\
\hline Episcopal & 0 & 1 & 0.29 & 0 & 0.45 \\
Bishop & 0 & 1 & 0.16 & 0 & 0.37 \\
Archbishop & 0 & 1 & 0.13 & 0 & 0.33 \\
Free or imperial & 0 & 1 & 0.13 & 0 & 0.34 \\
Free & 0 & 1 & 0.14 & 0 & 0.34 \\
Imperial & 0 & 1 & 0.06 & 0 & 0.23 \\
Prince & 0 & 1 & 0.57 & 1 & 0.49 \\
Count of dominion parties & 1 & 6 & 1.31 & 1 & 0.61 \\
Schöffen & 0 & 1 & 0.10 & 0 & 0.30 \\
Market development & 0 & 3 & 0.64 & 0 & 0.89 \\
Foreign moneylenders & 0 & 1 & 0.04 & 0 & 0.20 \\
Mint & 0 & 1 & 0.17 & 0 & 0.38 \\
Jewish community development & 0 & 4 & 0.53 & 0 & 0.96 \\
Total previous persecutions & 0 & 6 & 0.80 & 0 & 1.07 \\
Total previous expulsions & 0 & 4 & 0.05 & 0 & 0.29 \\
\hline
\end{tabular}

\section{Statistical method}

Event history analysis is a common method for explaining trends in political action, among other phenomena. Its applications range from racial riots (Braun 2011; Myers 2010) to the founding of labor organizations (Hedström, Sandell, and Stern 2000) to the adoption of laws internationally (Berliner 2014; Dawson and Swiss 2020) and in the United States (Bricker and 
LaCombe 2020). When events are observed in longer, discrete periods, such as in years instead of days or months, discrete-time methods are appropriate. Discrete-time event history analysis is the same as performing time-series logistic regression. Functionally, the model includes both (a) individual unit-level factors and (b) a diffusion hazard, which can be spatially and temporally adjusted (Strang and Tuma 1993).

Modeling a binary outcome can be difficult in social scientific studies, since we often have many independent or control variables. A complicated right side of a logistic regression model is likely to produce separation in the binary outcome. The co-occurrence of a few conditions will be associated only with 1's, while the co-occurrence of others will be associated only with 0's. Standard logistic regression will overestimate coefficients for rare events or fail to converge. Because the dependent variable of expulsion is a rare event (105 of 36,182 observations), and compounded by the fact that many of the independent variables are binary as well as sparsely distributed, I use a Bayesian logistic regression, as proposed by Gelman, Jakulin, Pittau, and Su (2008).

A Bayesian model requires the specification of a prior probability distribution, meaning an assumption or guess about what the distributions of the data are, and updates these prior distributions through checking the sample data. The updated information about variable distributions, or the posterior distribution, is then used in the regression. Instead of treating the patterns observed in the sample as "truth," a Bayesian regression introduces uncertainty around the sample distributions, with the results that separation is less likely and model convergence more likely.

In the case of a rare event, Gelman et al. (2008) and others (Betancourt 2017; Stan Development Team 2018a) argue for standardizing non-binary variables around 0 and rescaling to a standard deviation of 0.5 before using the weakly informative (Lemoine 2019; McElreath 2016) Student's t distribution $(\mathrm{df}=7$, scale $=2.5)$ for prior probability distributions. With the rstanarm package 2.18.2 (Stan Development Team 2018b) for R, I estimate Markov Chain Monte Carlo Bayesian hierarchical logistic regressions, with random effects for periodized settlement observations (since several covariates are period-based) nested within settlements. I use random effects because I am not interested in explaining effects of particular settlements, only in minimizing the influence of correlated errors within settlements. I use the Student's half-t 
distribution $(\mathrm{df}=4$, scale $=1)$ for weakly informative prior probability distributions for the intercepts (Gelman 2006).

To obtain posterior probability distributions, for each model specification I iterated through 5 independent chains 5,000 times each, starting with 2,500 warm-up iterations per chain. Full model details and diagnostic checks are described in the supplementary materials. Diagnostics did not detect any problematic behavior.

\section{RESULTS}

Table 4 displays the main event history analysis results using the rescaled sample data under six model specifications. Results are robust to varying the temporal window from 10 years to 5 years and to 20 years (see supplementary materials). Bayesian regression analyses produce posterior distributions for each component of a model that represent the joint distribution of the independent and dependent variables based on the observed data and the prior distributions provided by the analyst. Because of how the sample data were rescaled, for continuous variables the posterior median represents the effect of a 2-standard-error increase in the variable value instead of a one-unit increase. Since logistic regressions produce values showing change in logodds, which can be difficult to interpret, Figure 3 translates these values visually into changes in probabilities and credibility intervals for the main diffusion-related variables for each model. Credibility intervals capture a set percent of the density of a posterior distribution. Following McElreath (2016), I illustrate $89 \%$ credibility intervals, as well as 50\% intervals. The coefficients from logistic regressions are conditional on which other variables are included, so it is unwise to compare magnitudes across models (Breen, Karlson, and Holm 2018).

Models 1 and 2 focus on the potential impact of exposure and technical learning. The Model 1 results indicate expulsion was less likely with exposure to recent expulsions. The odds of expulsion were $49 \%$ lower when the count of expulsions in the previous 10 years (Dif1) was two standard deviations below ( 0 expulsions $\left.{ }^{6}\right)$ the mean (6.97 expulsions). The pattern is the opposite of the expected temporal spike in expulsions, if cities were learning about expulsion and its technical utility. Model 2 suggests that expulsions were less likely in cities where other expulsions had occurred recently and nearby. Across both models, there is no evidence that

\footnotetext{
6 Technically, two standard deviations below the mean of Dif 1 is less than 0. I substitute 0 here.
} 
participating in regional alliances or incorporation in the region via transit routes ${ }^{7}$ had anything to do with expulsions.

Model 3 assesses the importance of changes in social meaning inaugurated by the Council of Constance. Most expulsions occurred after the Council, and the regression analysis results confirm a strong relationship. At the same time, the temporal lag (Dif1) washes out. Additionally, the negative relationship between expulsions and distance from Constance appears to substantiate that expulsion spread outwards from Constance. There is no evidence that episcopal governors were the more likely adopters of this new behavior. Indeed, none of the models presented here validate that idea. Model 4 demonstrates this most clearly, as well as addressing the question of whether some set of prestigious cities induced other cities to expel. The model 4 results do not provide evidence that expulsion spread among either cities ruled by bishops or archbishops or free or imperial cities, or that expulsions among either of these groups catalyzed wider adoption of expulsion among other cities. These results are also inconsistent with an expectation of isomorphic conforming among a broad group of cities.

\footnotetext{
${ }^{7}$ The rarity of expulsion was not an effect of ignorance about the policy idea. Roads and rivers crisscrossed the western Holy Roman Empire. The median distance for a sample city to a river or road is 2.3 kilometers. Couriers were known to travel up to 65 kilometers in a day (Kreutz 2005).
} 
Table 4. Results of Bayesian Discrete-Time Event-History Models of Local Expulsions

\begin{tabular}{|c|c|c|c|c|c|c|c|c|c|c|c|c|}
\hline & $(1)$ & & $(2)$ & & (3) & & (4) & & $(5)$ & & (6) & \\
\hline & Mean & SD & Mean & SD & Mean & SD & Mean & SD & Mean & SD & Mean & $\mathrm{SD}$ \\
\hline Dif1 & -0.68 & 0.32 & 0.18 & 0.50 & -0.35 & 1.48 & & & & & & \\
\hline Dif2 (any) & & & -1.00 & 0.48 & & & & & & & -1.3 & 0.35 \\
\hline Dif2 (free/imperial) & & & & & & & & & -0.82 & 0.4 & & \\
\hline Dif2 (episcopal) & & & & & & & & & -0.49 & 0.63 & & \\
\hline Dif3 (episcopal) & & & & & & & -1.33 & 2.91 & -1.02 & 2.91 & & \\
\hline Dif3 (free/imperial) & & & & & & & 0.2 & 0.36 & 0.86 & 0.47 & 0.5 & 0.36 \\
\hline $\begin{array}{l}\text { Dif3 (episc.) * } \\
\text { episc. }\end{array}$ & & & & & & & 0.71 & 2.93 & 0.85 & 2.92 & & \\
\hline $\begin{array}{l}\text { Dif3 (free/imp.) * } \\
\text { free/imp. }\end{array}$ & & & & & & & 0.11 & 0.41 & 0.31 & 0.44 & 0.26 & 0.41 \\
\hline $\begin{array}{l}\text { After Council of } \\
\text { Constance }\end{array}$ & & & & & 3.23 & 1.37 & & & & & & \\
\hline $\begin{array}{l}\text { Dif } 1 * \text { After } \\
\text { Constance }\end{array}$ & & & & & -0.72 & 1.49 & & & & & & \\
\hline Km to Constance & & & & & -1.08 & 0.49 & -1.07 & 0.43 & -1.1 & 0.43 & & \\
\hline $\begin{array}{l}\text { Count of Travel } \\
\text { Routes }\end{array}$ & & & -0.30 & 0.35 & & & & & & & & \\
\hline $\begin{array}{l}\text { Total Prior Alliance } \\
\text { Treaties }\end{array}$ & 0.34 & 0.32 & 0.32 & 0.30 & & & & & & & & \\
\hline Bishop & -0.37 & 0.64 & -0.34 & 0.63 & -0.19 & 0.68 & & & & & & \\
\hline Archbishop & -0.29 & 0.65 & -0.12 & 0.65 & -0.09 & 0.68 & & & & & & \\
\hline Episcopal & & & & & & & 0.51 & 0.88 & 0.5 & 0.88 & -0.3 & 0.51 \\
\hline Free & 0.82 & 0.58 & 0.82 & 0.55 & 0.58 & 0.60 & & & & & & \\
\hline Imperial & -0.15 & 0.74 & -0.12 & 0.72 & 0.07 & 0.75 & & & & & & \\
\hline Free or imperial & & & & & & & 0.06 & 0.62 & -0.12 & 0.63 & 0.11 & 0.59 \\
\hline
\end{tabular}




\begin{tabular}{|c|c|c|c|c|c|c|c|c|c|c|c|c|}
\hline Prince & -0.16 & 0.5 & -0.14 & 0.48 & -0.1 & 0.52 & -0.12 & 0.51 & -0.13 & 0.52 & -0.18 & 0.49 \\
\hline Global Intercept & -10.02 & 0.93 & -9.65 & 0.88 & -11.28 & 1.45 & -10.03 & 1.13 & -10.1 & 1.14 & -9.52 & 0.86 \\
\hline $\begin{array}{l}\text { Nested random } \\
\text { effects }\end{array}$ & Yes & & Yes & & Yes & & Yes & & Yes & & Yes & \\
\hline Log-posterior & -2976.16 & & -2985.73 & & -2960.65 & & -2983.26 & & -2980.67 & & -2980.04 & \\
\hline
\end{tabular}


The results for model 5 demonstrate that multiple mechanisms jointly produce the spread of expulsion among some cities and the suppression of expulsion among others. In model 5, I modeled the probability of expulsion in relationship to other cities' social and structural positions, behavior, and proximity. The results show three important features. First, expulsion was more likely when free or imperial cities had done so recently. For observations two standard deviations above the mean (3.72) of Dif3(free/imperial), the odds of expulsion were $136 \%$ greater than observations at the mean (0.52). Second, expulsions were less likely in cities nearby to the expelling free or imperial cities. Dif2(free/imperial) increases with more expulsions and with greater proximity to expulsions. For a city whose Dif2(free/imperial) value in a year is two standard deviations above (0.56) the mean (0.06), the odds of expulsion are 56\% lower. Third, distance to Constance remains important even after including these other layers of temporal and spatial measures; cities nearer to Constance were more likely to expel their Jewish residents. Additionally, I included interactions between each categorical temporal lag and dummy variables for whether a city was of that same type, which detects whether episcopal cities, or free or imperial cities, responded differently to expulsions in cities of their same type than did other cities. I find no evidence for a difference in temporal effects. Expulsions among free and imperial cities did not accelerate expulsions within that group alone.

Model 6 explores the limits of these results. The negative relationship with the only spatial independent variable, plus the non-importance of the one temporal measure, underscores the role of space in medieval German expulsions of Jews. The persistent negative spatial pattern is consistent with the interpretation that expulsion displaced Jews into cities that benefited from and valued their new residents economically. Unfortunately, we only have some records of the localities in which displaced Jews resettled, but at least some did move only a short distance.

Regarding the local incentives for expulsion, this study mostly agrees with others that stress domestic political economy. Across the model specifications, estimates for local factors reinforce the view that the distribution of resources among cities shaped what choices were made about the institutionalization of social closure. Jews were more vulnerable to expulsion in cities where there were foreign moneylenders and where there was a local mint, both sources of city funding. Expulsions happened less often in cities run by boards of jurists (Schöffen). Each city had its own arrangements of political power and economic development. Expulsions were undertaken in the midst of struggles over authority and legitimacy (Doten-Snitker 2021; Finley 
and Koyama 2018; Johnson and Koyama 2019; Grzymała-Busse 2020) that were endogenous to some institutional arrangements. Once these institutional contexts and the social factors between cities are accounted for, the types of parties to dominion over a city did not matter. Trends support the conclusion that local conditions were the prevailing concern for cities.
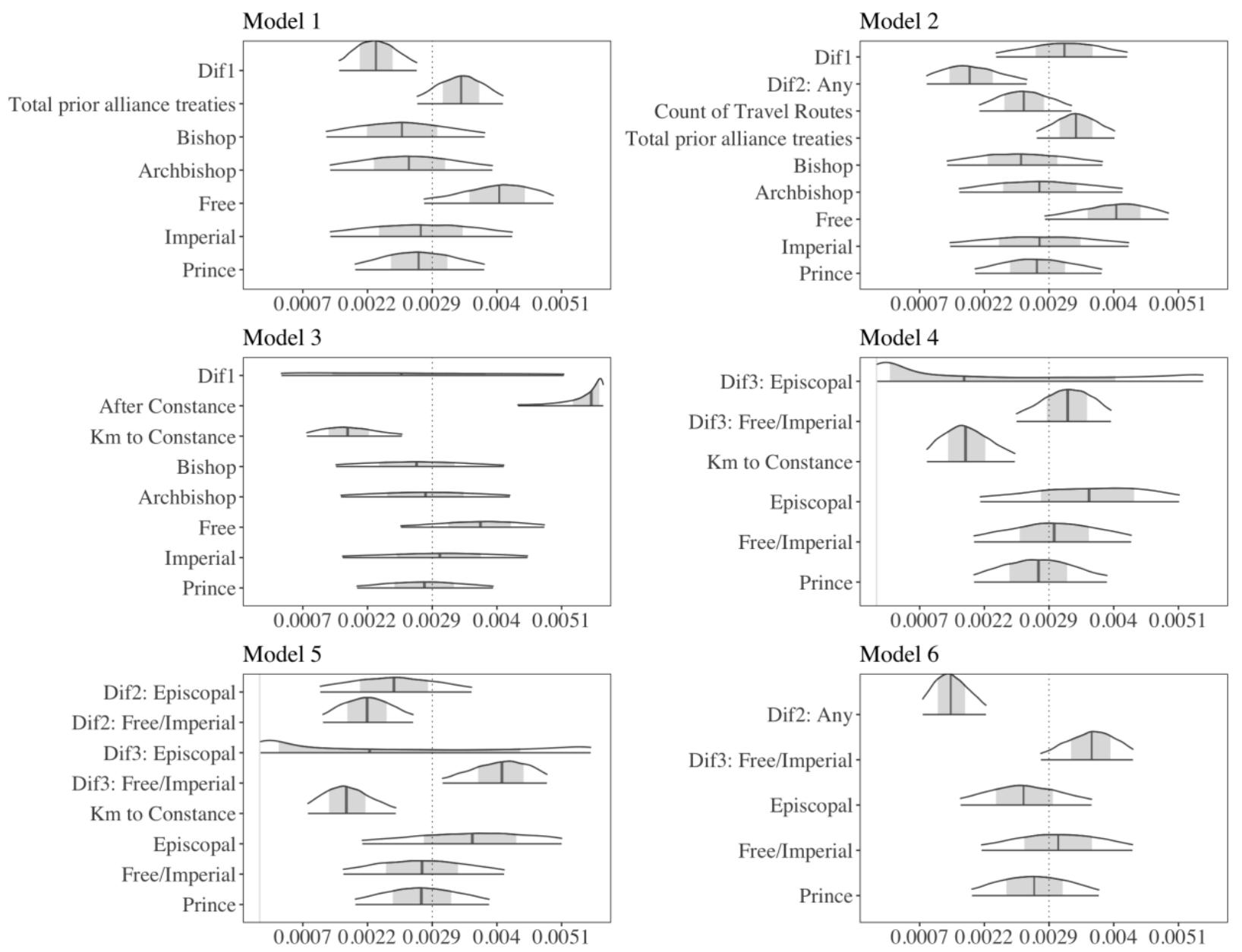

Figure 3. Posterior Distributions for Diffusion-related Effects, Transformed to Probabilities Note. Continuous variables scaled to $(0,0.5)$. Center lines are posterior medians. Shaded intervals are $50 \%$ credibility intervals; distribution outlines are $89 \%$ credibility intervals.

The results also point to patterns in local interreligious cultures. Cities with more prior persecutions were more likely to expel their Jewish residents, as were cities with more Jewish community infrastructure. I cannot tell from these data and methods whether the relationship between Jewish community development and expulsions is one of community size and therefore 
visibility as religious others or valuable confiscable assets. The relationship between Jewish community features and their treatment by their neighbors is a good avenue for future research, as more contemporary investigations about minority groups provide several hypotheses about whether contact, visibility, or economics drive exclusion and targeted political violence.

\section{DISCUSSION AND CONCLUSION}

This study addresses the persistent question of where social boundaries come from, and why they take the institutional forms they take (Quisumbing King 2019; Johnson and Koyama 2019). Shared social hierarchies are not sufficient for importing (Tilly 1998) revised forms of exclusion. Social embeddedness affects how social closure is institutionalized, both in facilitating and constraining policy variation. Using a dataset of medieval German city histories, I weighed internal and network factors for why expulsions of Jews increased but did not spread widely. In several ways, social influence checked the spread of this change in social closure. There was no widespread adoption pattern following exposure to expulsions or learning about expulsions' technical value. Social meaning and norms mattered insofar as cultural change about the religio-political meaning of Jewish incorporation opened the possibility for theocratic rationales for expulsions, especially for more autonomous cities. Local resource dependency suppressed the incidence of subsequent expulsion in nearby cities.

When we pull back from the enactment of a single expulsion to the broader sociopolitical context, one of authority contests, geopolitical jostling, and theocratic elaboration, we recognize that social closure was a strategy in a broader contest that not all polities were participating in. Rather than institutional diffusion of antisemitic social closure, expulsion became part of a repertoire of contention (Barkey and Van Rossem 1997; Bromley, Schofer, and Longhofer 2020; McAdam, Tarrow, and Tilly 2001). As a tactic of governance and authority contestation, expulsion was shared across cities after cultural change gave it new credibility. Complete social closure itself does not have to be a political goal in order for exclusion to be legislated (Bracey 2015; Ray 2019; Boushey 2016). Rather, in pursuit of other objectives, governments deploy new institutionalizations of exclusion, manipulating social boundaries for decidedly non-ethnoracial ends.

We have much to explore still in how inter-government relationships matter for changing institutionalizations and maintaining old ones. One of the better-explored lines of research asks 
how governments are embedded in broader shared cultural contexts and networks of meaning, on global and regional scales (Cook-Martín and FitzGerald 2019). For medieval German cities, the broader context included the norm of non-expulsion and then new emphasis on theocracy in the fifteenth century that undermined the Latin Church's monopoly on religious authority (Blickle 1992; Doten-Snitker 2021) as well as the emperor's secular authority. Scholars interrogating world society theory are the leading edge here (Cole and Perrier 2019; Leffel 2022). Most of this work concerns policies about sexual orientations and gender identities (Ferguson 2021; Gonsalves 2021; Velasco 2018). There are many opportunities for observing how social influence relates to sociolegal heritage and ideologies, such as the advent of modern democracy or of eugenics (Sánchez-Rivera 2021), to foster global or regional adherence (Cederman, Gleditsch, and Wucherpfennig 2018) to one rule of social closure versus another.

But how powerful is shared culture, relative to structures of status and power? World society theory and similar meaning-based explanations are limited in how they can account for hierarchy and its constrictions on actions (Beckfield 2008; 2010; Downey et al. 2020). In medieval Germany, cultural change interacted with the existing power structure such that the social and internal constraints on expulsion persisted among smaller dependencies, but were loosened for cities with greater political and economic privileges. We should pay as much attention to distributions of political and economic power as we do to presumed ideological alignment (Barkey and Van Rossem 1997; Hannah and Mallinson 2018; Weyland 2017) in government-led exclusion and violence against minority groups. For some governments, institutional divergence (Beckert 2010) can be a competitive edge (Barnett, Xiao, and Zhou 2021). Power structures and position might incentivize complementary policies, rather than identical ones (Jorgenson 2009; 2010); coercive influence can keep less powerful governments from adopting the same policies of social closure as more powerful governments.

Further, this study prompts closer examination of social influence works spatially (Xu and Tian 2020). It affirms the value of the growing research body examining how space and ethnic or racial extremism are related (Hoerner, Jaax, and Rodon 2019; Homola, Pereira, and Tavits 2020; Pepinsky, Goodman, and Ziller 2020). Diffusion research often looks to proximity as a facilitator, which may be appropriate for some types of extremism (Andrews and Seguin 2015; Cederman, Gleditsch, and Wucherpfennig 2018). However, in contrast to conventional understanding, this study demonstrates that proximity can hamper diffusion, too (Mitchell and 
Toner 2016). Proximity signifies different types of relationships in different eras and places. How those relationships vary, and what that variation means for social closure and for policy diffusion generally, remains an open question.

Finally, this study offers three recommendations for studies of the state and of diffusion. First, we need more studies of the absence of political change. Instead of searching only for what ties assist the spread of exclusion or violence, studies should look for what kinds of social influence arrest it. In doing so, we can tackle the general question of how much the absence of change is a function of the difficulty of institutionalizing something versus a function of how social influences are stacked against a new policy. Second, scholars should continue to be creative when network data is unavailable or systematically impossible. This study used one strategy, updating an existing and accepted formula. My combination of event-history methods with the concept of adjacency matrices from network analysis may help other researchers who face issues with reconstructing social networks.

Third, and perhaps most importantly, we should investigate whether and how much theories of diffusion should be tailored to different political domains. While cultural context, network structure, and consequences (Centola and Macy 2007; Goldberg and Stein 2018; Kreindler and Young 2014) are all important ingredients in recipes for stasis or change, one important limitation to our understanding of diffusion is in how actions or policies themselves are interchangeable or not. Surely we do not expect that cultural policies about inclusion and exclusion (Hummel 2021) are subject to exactly the same mechanisms of diffusion as policies about environmental quality and sustainability (Goes forthcoming), legal reforms (Dawson and Swiss 2020), or zoning and housing (Butler et al. 2017). And how and when are policies about LGBT persons, gender, or religion comparable with the diffusion of policies about ethnoracial groups? Further comparative work on the institutionalization of social boundaries can help us test the limits of diffusion theories as well as compare policy development on cultural matters versus the aspects that are often considered more technical. 


\section{REFERENCES}

Abrutyn, Seth, Anna S. Mueller, and Melissa Osborne. 2019. "Rekeying Cultural Scripts for Youth Suicide: How Social Networks Facilitate Suicide Diffusion and Suicide Clusters Following Exposure to Suicide." Society and Mental Health 10 (2): 112-35. https://doi.org/10.1177/2156869319834063.

Acharya, Amitav. 2011. "Norm Subsidiarity and Regional Orders: Sovereignty, Regionalism, and Rule-Making in the Third World." International Studies Quarterly 55 (1): 95-123. https://doi.org/10.1111/j.1468-2478.2010.00637.x.

Aidt, Toke, Gabriel Leon-Ablan, and Max Satchell. 2022. "The Social Dynamics of Collective Action: Evidence from the Diffusion of the Swing Riots, 1830-1831.” The Journal of Politics 84 (1): 209-25. https://doi.org/10.1086/714784.

Anderson, Warren, Noel D. Johnson, and Mark Koyama. 2017. "Jewish Persecutions and Weather Shocks: 1100-1800.” The Economic Journal 127 (602): 924-58. https://doi.org/10.1111/ecoj.12331.

Andrews, Kenneth T, and Michael Biggs. 2006. "The Dynamics of Protest Diffusion: Movement Organizations, Social Networks, and News Media in the 1960 Sit-Ins.” American Sociological Review 71 (5): 752-77.

Andrews, Kenneth T., and Charles Seguin. 2015. "Group Threat and Policy Change: The Spatial Dynamics of Prohibition Politics, 1890-1919." American Journal of Sociology 121 (2): 475-510. https://doi.org/10.1086/682134.

Bail, Christopher A., Taylor W. Brown, and Andreas Wimmer. 2019. "Prestige, Proximity, and Prejudice: How Google Search Terms Diffuse Across the World." American Journal of Sociology 124 (5): 1496-1548. https://doi.org/10.1086/702007.

Barkey, Karen, and Ira Katznelson. 2011. "States, Regimes, and Decisions: Why Jews Were Expelled from Medieval England and France." Theory and Society 40 (5): 475-503. https://doi.org/10.1007/s11186-011-9150-8.

Barkey, Karen, and Ronan Van Rossem. 1997. "Networks of Contention: Villages and Regional Structure in the Seventeenth-Century Ottoman Empire.” American Journal of Sociology 102 (5): 1345-82. https://doi.org/10.1086/231086.

Barnett, William P., Xiao Xiao, and Yi Zhou. 2021. "Competitive Exclusion versus Mimetic Isomorphism: An Identified Empirical Test.” Sociological Science 8 (June): 211-29. https://doi.org/10.15195/v8.a11.

Bartlett, Robert. 2001. "Medieval and Modern Concepts of Race and Ethnicity." Journal of Medieval and Early Modern Studies 31 (1): 39-56. https://doi.org/10.1215/10829636-311-39.

Barzel, Yoram. 1992. "Confiscation by the Ruler: The Rise and Fall of Jewish Lending in the Middle Ages." Journal of Law and Economics 35 (1): 1-13.

Battenberg, J. Friedrich. 1987. “Des Kaiser's Kammerknechte. Gedanken zur rechtlich-sozialen Situation der Juden in Spätmittelalter und früher Neuzeit." Historische Zeitschrift 245 (3): 545-99. https://doi.org/10.1524/hzhz.1987.245.jg.545.

Bauer, Michal, Jana Cahlíková, Julie Chytilová, and Tomáš Želinský. 2018. "Social Contagion of Ethnic Hostility." Proceedings of the National Academy of Sciences 115 (19): 488186. https://doi.org/10.1073/pnas.1720317115.

Beck, Nathaniel, Kristian Skrede Gleditsch, and Kyle Beardsley. 2006. "Space Is More than Geography: Using Spatial Econometrics in the Study of Political Economy." 
International Studies Quarterly 50 (1): 27-44. https://doi.org/10.1111/j.14682478.2006.00391.x.

Becker, Sascha O., Yuan Hsiao, Steven Pfaff, and Jared Rubin. 2020. "Multiplex Network Ties and the Spatial Diffusion of Radical Innovations: Martin Luther's Leadership in the Early Reformation." American Sociological Review 85 (5): 857-94. https://doi.org/10.1177/0003122420948059.

Beckert, Jens. 2010. "Institutional Isomorphism Revisited: Convergence and Divergence in Institutional Change." Sociological Theory 28 (2): 150-66. https://doi.org/10.1111/j.1467-9558.2010.01369.x.

Beckfield, Jason. 2008. "The Dual World Polity: Fragmentation and Integration in the Network of Intergovernmental Organizations." Social Problems 55 (3): 419-42. https://doi.org/10.1525/sp.2008.55.3.419. . 2010. "The Social Structure of the World Polity." American Journal of Sociology 115 (4).

Berliner, Daniel. 2014. "The Political Origins of Transparency.” The Journal of Politics 76 (02): 479-91. https://doi.org/10.1017/S0022381613001412.

Betancourt, Michael. 2017. "How the Shape of a Weakly Informative Prior Affects Inferences." March 17, 2017. http://mc-stan.org/users/documentation/casestudies/weakly_informative_shapes.html.

Blickle, Peter. 1992. Communal Reformation: The Quest for Salvation in Sixteenth-Century Germany. Atlantic Highlands, N.J.: Humanities Press.

Börner, René. 2010. "Die Ungleichheit von Schöffen und Berufsrichtern - Schöffen als Garanten der Unmittelbarkeit -." Zeitschrift für die gesamte Strafrechtswissenschaft 122 (1): 15798. https://doi.org/10.1515/zstw.2010.157.

Bossak, Brian H., and Mark R. Welford. 2015. "Spatio-Temporal Characteristics of the Medieval Black Death." In Spatial Analysis in Health Geography, edited by Pavlos Kanaroglu, Eric Delmelle, and Antonio Páez, 71-84. New York: Routledge.

Botticini, Maristella. 2000. "A Tale of 'Benevolent' Governments: Private Credit Markets, Public Finance, and the Role of Jewish Lenders in Medieval and Renaissance Italy." The Journal of Economic History 60 (1): 164-89.

Boushey, Graeme. 2016. "Targeted for Diffusion? How the Use and Acceptance of Stereotypes Shape the Diffusion of Criminal Justice Policy Innovations in the American States." American Political Science Review 110 (1): 198-214. https://doi.org/10.1017/S0003055415000532.

Bracey, Glenn E. 2015. “Toward a Critical Race Theory of State.” Critical Sociology 41 (3): 553-72. https://doi.org/10.1177/0896920513504600.

Braun, Robert. 2011. "The Diffusion of Racist Violence in the Netherlands: Discourse and Distance." Journal of Peace Research 48 (6): 753-66. https://doi.org/10.1177/0022343311419238.

—. 2016. "Religious Minorities and High Risk Mobilization: The Collective Rescue of Jews in the Netherlands during the Holocaust." American Political Science Review 110 (1): 127-47. https://doi.org/10.1017/S0003055415000544.

Braun, Robert, and Michael Genkin. 2013. "Cultural Resonance and the Diffusion of Suicide Bombings: The Role of Collectivism." Journal of Conflict Resolution 58 (7): 1258-84. https://doi.org/10.1177/0022002713498707. 
Breen, Richard, Kristian Bernt Karlson, and Anders Holm. 2018. "Interpreting and Understanding Logits, Probits, and Other Nonlinear Probability Models." Annual Review of Sociology 44 (1): 39-54. https://doi.org/10.1146/annurev-soc-073117-041429.

Bricker, Christine, and Scott LaCombe. 2020. "The Ties That Bind Us: The Influence of Perceived State Similarity on Policy Diffusion." Political Research Quarterly, February. https://doi.org/10.1177/1065912920906611.

Bromley, Patricia, Evan Schofer, and Wesley Longhofer. 2020. "Contentions over World Culture: The Rise of Legal Restrictions on Foreign Funding to NGOs, 1994-2015." Social Forces 99 (1): 281-304. https://doi.org/10.1093/sf/soz138.

Brooke, Steven, and Neil Ketchley. 2018. "Social and Institutional Origins of Political Islam." American Political Science Review 112 (2): 376-94. https://doi.org/10.1017/S0003055417000636.

Brown, Gustav. 2019. "Conforming Choices: Peer Influence, Adoption, and Interpretation of the Islamic Headscarf in Indonesia." Sociology of Religion 80 (3): 372-98. https://doi.org/10.1093/socrel/sry057.

Brubaker, Rogers. 2004. Ethnicity Without Groups. Cambridge, MA: Harvard University Press.

Burt, Ronald S. 1987. "Social Contagion and Innovation." American Journal of Sociology 92 (6): 1287-1335. http://www.jstor.org/stable/2779839.

Butler, Daniel M., Craig Volden, Adam M. Dynes, and Boris Shor. 2017. "Ideology, Learning, and Policy Diffusion: Experimental Evidence." American Journal of Political Science 61 (1): 37-49. https://doi.org/10.1111/ajps.12213.

Cantoni, Davide. 2012. "Adopting a New Religion: The Case of Protestantism in 16th Century Germany." Economic Journal 122 (560): 502-31. https://doi.org/10.1111/j.14680297.2012.02495.x.

Cederman, Lars-Erik, Kristian Skrede Gleditsch, and Julian Wucherpfennig. 2018. "The Diffusion of Inclusion: An Open-Polity Model of Ethnic Power Sharing." Comparative Political Studies 51 (10): 1279-1313. https://doi.org/10.1177/0010414017740602.

Centola, Damon. 2015. "The Social Origins of Networks and Diffusion.” American Journal of Sociology 120 (5): 1295-1338. https://doi.org/10.1086/681275.

- 2018. How Behavior Spreads: The Science of Complex Contagions. Princeton, N.J.: Princeton University Press.

Centola, Damon, and Michael Macy. 2007. "Complex Contagions and the Weakness of Long Ties.” American Journal of Sociology 113 (3): 702-34. https://doi.org/10.1086/521848.

Chilosi, David, and Oliver Volckart. 2011. "Money, States, and Empire: Financial Integration and Institutional Change in Central Europe, 1400-1520." The Journal of Economic History 71 (3): 762-91. https://doi.org/10.1017/S0022050711001914.

Clemens, Elisabeth S., and James M. Cook. 1999. "Politics and Institutionalism: Explaining Durability and Change." Annual Review of Sociology 25 (1): 441-66. https://doi.org/10.1146/annurev.soc.25.1.441.

Cluse, Christoph. 1999. "Zum Zusammenhang von Wuchervorwurf und Judenvertreibung im 13. Jahrhundert." In Judenvertreibungen in Mittelalter und früher Neuzeit, edited by Friedhelm Burgard, Alfred Haverkamp, and Gerd Mentgen, 135-64. Hannover: Hahn. . 2009. "Jewish Community and Civic Commune in the High Middle Ages." In Strangers and Poor People: Changing Patterns of Inclusion and Exclusion in Europe and the Mediterranean World from Classical Antiquity to the Present Day, edited by Andreas Gestrich, Lutz Raphael, and Herbert Uerlings, 2-6. Frankfurt: Peter Lang. 
Cluse, Christoph, and Jorg R Müller. 2009. "Jewish Communities in Germany in the Mid Fourteenth Century." In Treasures of the Black Death, edited by Claire Descatoire, 2227. London: The Wallace Collection.

Cole, Wade M, and Gaëlle Perrier. 2019. "Political Equality for Women and the Poor: Assessing the Effects and Limits of World Society, 1975-2010." International Journal of Comparative Sociology 60 (3): 140-72. https://doi.org/10.1177/0020715219831422.

Cook-Martín, David, and David Scott FitzGerald. 2019. "How Their Laws Affect Our Laws: Mechanisms of Immigration Policy Diffusion in the Americas, 1790-2010." Law \& Society Review 53 (1): 41-76. https://doi.org/10.1111/lasr.12394.

Darman, Ashkira. 2009. "Stewren, raisen, wachen, schenken: Steuern und Rechte jüdischer Bürger im Vergleich mit christlichen rechtlichen Gruppen und im Rahmen des städtischen Finanzhaushaltes in Reichsstädten im Südwesten des Reiches (1350-1500).” Dissertation, Zürich: University of Zurich, Faculty of Arts. https://doi.org/info:doi/10.5167/uzh-163842.

Darwich, May. 2017. "Creating the Enemy, Constructing the Threat: The Diffusion of Repression against the Muslim Brotherhood in the Middle East." Democratization 24 (7): 1289-1306. https://doi.org/10.1080/13510347.2017.1307824.

Dawson, Andrew, and Liam Swiss. 2020. "Foreign Aid and the Rule of Law: Institutional Diffusion versus Legal Reach.” The British Journal of Sociology. https://doi.org/10.1111/1468-4446.12752.

DeMora, Stephanie L., Loren Collingwood, and Adriana Ninci. 2019. "The Role of Super Interest Groups in Public Policy Diffusion.” Policy \& Politics 47 (4): 513-41. https://doi.org/10.1332/030557319X15659214258414.

DiMaggio, Paul J., and Walter W. Powell. 1983. "The Iron Cage Revisited: Institutional Isomorphism and Collective Rationality in Organizational Fields." American Sociological Review 48 (2): 147-60. http://www.jstor.org/stable/2095101.

Distler, Eva-Marie. 2006. Städtebünde im deutschen Spätmittelalter: eine rechtshistorische Untersuchung zu Begriff, Verfassung und Funktion. Frankfurt am Main: Klostermann.

Dittmar, Jeremiah E. 2011. "Information Technology and Economic Change: The Impact of The Printing Press.” The Quarterly Journal of Economics 126 (3): 1133-72. https://doi.org/10.1093/qje/qjr035.

Dixon, Marc, and Vincent J. Roscigno. 2003. "Status, Networks, and Social Movement Participation: The Case of Striking Workers." American Journal of Sociology 108 (6): 1292-1327. https://doi.org/10.1086/375198.

Dobbin, Frank, Beth Simmons, and Geoffrey Garrett. 2007. "The Global Diffusion of Public Policies: Social Construction, Coercion, Competition, or Learning?" Annual Review of Sociology 33 (1): 449-72. https://doi.org/10.1146/annurev.soc.33.090106.142507.

Dorin, Rowan W. 2015. "Banishing Usury: The Expulsion of Foreign Moneylenders in Medieval Europe, 1200-1450.” Doctoral dissertation, Boston, Mass.: Harvard University, Graduate School of Arts \& Sciences. http://nrs.harvard.edu/urn-3:HUL.InstRepos:23845403. . 2016. "“Once the Jews Have Been Expelled': Intent and Interpretation in Late Medieval Canon Law." Law and History Review 34 (02): 335-62. https://doi.org/10.1017/S0738248016000043. . 2023. No Return: Jews, Christian Usurers, and the Spread of Mass Expulsion in Medieval Europe. Princeton, N.J.: Princeton University Press. 
Doten-Snitker, Kerice. 2021. "Contexts of State Violence: Jewish Expulsions in the Holy Roman Empire.” Social Science History 45 (1): 131-63. https://doi.org/10.1017/ssh.2020.39.

Downey, Liam, Elizabeth Lawrence, Micah Pyles, and Derek Lee. 2020. "Power, Hegemony, and World Society Theory: A Critical Evaluation.” Socius 6 (January): 2378023120920059. https://doi.org/10.1177/2378023120920059.

Eiden, Herbert, and Franz Irsigler. 2000. "Environs and Hinterland: Cologne and Nuremberg in the Later Middle Ages." In Trade, Urban Hinterlands, and Market Integration, c. 13001500, edited by James A. Galloway, 43-57. Center for Metropolitan History Working Paper Series 3. London: Centre for Metropolitan History-Institute of Historical Research.

Evers, Miles M. 2017. “On Transgression.” International Studies Quarterly 61 (4): 786-94. https://doi.org/10.1093/isq/sqx065.

Ferguson, Jason L. 2021. “"There Is an Eye on Us': International Imitation, Popular Representation, and the Regulation of Homosexuality in Senegal." American Sociological Review, August, 00031224211026546. https://doi.org/10.1177/00031224211026546.

Fiel, Jeremy E. 2013. "Decomposing School Resegregation: Social Closure, Racial Imbalance, and Racial Isolation." American Sociological Review 78 (5): 828-48. https://doi.org/10.1177/0003122413496252.

Fields, Karen E., and Barbara Jeanne Fields. 2014. Racecraft: The Soul of Inequality in American Life. Verso Books.

Finley, Theresa, and Mark Koyama. 2018. "Plague, Politics, and Pogroms: The Black Death, the Rule of Law, and the Persecution of Jews in the Holy Roman Empire." The Journal of Law and Economics 61 (2): 253-77. https://doi.org/10.1086/699016.

Fisher, Dana R., William Yagatich, and Anya Galli Robertson. 2017. "Onto the Street and Into the Movement: Understanding How Social Movements Expand Their Reach through Large-Scale Protest Events." OSF Preprints, May. https://doi.org/10.31219/osf.io/dyztw.

Gelman, Andrew. 2006. "Prior Distributions for Variance Parameters in Hierarchical Models (Comment on Article by Browne and Draper)." Bayesian Analysis 1 (3): 515-34. https://doi.org/10.1214/06-BA117A.

Gelman, Andrew, Aleks Jakulin, Maria Grazia Pittau, and Yu Sung Su. 2008. "A Weakly Informative Default Prior Distribution for Logistic and Other Regression Models." Annals of Applied Statistics 2 (4): 1360-83. https://doi.org/10.1214/08-AOAS191.

Gilardi, Fabrizio, and Claudio M. Radaelli. 2012. "Governance and Learning." Edited by David Levi-Faur. The Oxford Handbook of Governance, March. https://doi.org/10.1093/oxfordhb/9780199560530.013.0011.

Gilardi, Fabrizio, Charles R Shipan, and Bruno Wüest. 2021. "Policy Diffusion: The IssueDefinition Stage.” American Journal of Political Science 65 (1): 21-35. https://doi.org/10.1111/ajps.12521.

Gilardi, Fabrizio, and Fabio Wasserfallen. 2019. "The Politics of Policy Diffusion." European Journal of Political Research 58 (4): 1245-56. https://doi.org/10.1111/1475-6765.12326.

Gilomen, Hans-Jörg. 2009. "Kooperation und Konfrontation: Juden und Christen in den spätmittelalterlichen Städten im Gebiet der heutigen Schweiz.” In Juden in ihrer Umwelt: Akkulturation des Judentums in Antike und Mittelalter, edited by Matthias Konradt and Rainer C. Schwinges, 157-227. Basel: Schwabe. https://doi.org/10.5167/uzh-26184. 
Go, Julian, and Jake Watson. 2019. "Anticolonial Nationalism: From Imagined Communities to Colonial Conflict.” European Journal of Sociology / Archives Européennes de Sociologie 60 (1): 31-68. https://doi.org/10.1017/S000397561900002X.

Goes, Iasmin. forthcoming. "Examining the Effect of IMF Conditionality on Natural Resource Policy.” Economics \& Politics. https://doi.org/10.1111/ecpo.12214.

Goldberg, Amir, and Sarah K. Stein. 2018. "Beyond Social Contagion: Associative Diffusion and the Emergence of Cultural Variation." American Sociological Review 83 (5): 897932. https://doi.org/10.1177/0003122418797576.

Gonsalves, Tara. 2021. “Transnational Diffusion and Regional Resistance: Domestic LGBT Association Founding, 1979-2009.” Social Forces 99 (4): 1601-30. https://doi.org/10.1093/sf/soaa068.

Grayzel, Solomon. 1967. "Jews and the Ecumenical Councils." The Jewish Quarterly Review 57: 287-311. https://doi.org/10.2307/1453498.

Greve, Henrich R., Ji-Yub (Jay) Kim, and Daphne Teh. 2016. "Ripples of Fear: The Diffusion of a Bank Panic." American Sociological Review 81 (2): 396-420. https://doi.org/10.1177/0003122416629611.

Grzymała-Busse, Anna. 2020. "Beyond War and Contracts: The Medieval and Religious Roots of the European State.” Annual Review of Political Science 23 (1): 19-36. https://doi.org/10.1146/annurev-polisci-050718-032628.

Hadden, Jennifer, and Lorien Jasny. 2019. "The Power of Peers: How Transnational Advocacy Networks Shape NGO Strategies on Climate Change." British Journal of Political Science 49 (2): 637-59. https://doi.org/10.1017/S0007123416000582.

Hagen, Christian. 2018. "Zwischen Privilegierung und Vertreibung - Die Ratspolitik gegenüber Juden in Konstanz und Esslingen während des 15. Jahrhunderts." In Reichsstadt und Geld: 5. Tagung des Mühlhäuser Arbeitskreises für Stadtgeschichte, Mühlhausen 27. Februar biz 1. März 2017, edited by Michael Rothmann and Helge Wittman, 229-42. Petersburg, Germany: Michael Imhof.

Hale, Henry E. 2008. The Foundations of Ethnic Politics: Separatism of States and Nations in Eurasia and the World. Cambridge: Cambridge University Press.

Hannah, A. Lee, and Daniel J. Mallinson. 2018. "Defiant Innovation: The Adoption of Medical Marijuana Laws in the American States.” Policy Studies Journal 46 (2): 402-23. https://doi.org/10.1111/psj.12211.

Hardy, Duncan. 2018. Associative Political Culture in the Holy Roman Empire: Upper Germany, 1346-1521. Oxford: Oxford University Press.

Haverkamp, Alfred. 1999. "Judenvertreibungen in Mittelalter und Frühneuzeit -Erscheinungsformen und Zusammenhänge, Betrachtungsweisen und Erkenntnischancen. Zur Orientierung." In Judenvertreibungen in Mittelalter und früher Neuzeit, edited by Friedhelm Burgard, Alfred Haverkamp, and Gerd Mentgen, 1-22. Hannover: Hahn. , ed. 2002. Geschichte der Juden im Mittelalter von der Nordsee bis zu den Südalpen: Kommentiertes Kartenwerk, 1: Kommentarband; 2: Ortskatalog; 3: Karten. Vol. 1-3. Forschungen zur Geschichte der Juden, A/14. Hannover: Hahnsche Buchhandlung. . 2004. "Europas Juden im Mittelalter: Zur Einführung." In Europas Juden im Mittelalter, 13-29. Trier, Germany: Kliomedia.

Hechter, Michael. 1987. Principles of Group Solidarity. Berkeley: University of California Press. 
Hedström, Peter. 1994. "Contagious Collectivities: On the Spatial Diffusion of Swedish Trade Unions, 1890-1940.” American Journal of Sociology 99 (5): 1157-79. https://doi.org/10.1086/230408.

Hedström, Peter, Rickard Sandell, and Charlotta Stern. 2000. "Mesolevel Networks and the Diffusion of Social Movements: The Case of the Swedish Social Democratic Party." American Journal of Sociology 106 (1): 145-72. https://doi.org/10.1086/303109.

Heng, Geraldine. 2018. The Invention of Race in the European Middle Ages. New York, NY; Cambridge, United Kingdom: Cambridge University Press.

Hijmans, Robert J. 2019. "Raster: Geographic Data Analysis and Modeling.” https://CRAN.Rproject.org/package=raster.

Hjerm, Mikael, Maureen A. Eger, Andrea Bohman, and Filip Fors Connolly. 2019. "A New Approach to the Study of Tolerance: Conceptualizing and Measuring Acceptance, Respect, and Appreciation of Difference.” Social Indicators Research, September. https://doi.org/10.1007/s11205-019-02176-y.

Hoerner, Julian M., Alexander Jaax, and Toni Rodon. 2019. "The Long-Term Impact of the Location of Concentration Camps on Radical-Right Voting in Germany." Research \& Politics 6 (4): 1-8. https://doi.org/10.1177/2053168019891376.

Homola, Jonathan, Miguel M. Pereira, and Margit Tavits. 2020. "Legacies of the Third Reich: Concentration Camps and Out-Group Intolerance." American Political Science Review 114 (2): 573-90. https://doi.org/10.1017/S0003055419000832.

Horowitz, Michael C. 2010. "Nonstate Actors and the Diffusion of Innovations: The Case of Suicide Terrorism.” International Organization 64 (1): 33-64. https://doi.org/10.1017/S0020818309990233.

Housley, Norman. 2017. “Crusade and Reform, 1414-1449: Allies or Rivals?” In Reconfiguring the Fifteenth-Century Crusade, edited by Norman Housley, 45-84. London: Palgrave Macmillan.

Hsiao, Yuan. 2022. "Network Diffusion of Competing Behaviors." Journal of Computational Social Science 5 (1): 47-68. https://doi.org/10.1007/s42001-021-00115-x.

Hummel, Daniel. 2021. Prejudice and Policymaking: Islamophobia in the United States and the Diffusion of Anti-Sharia Laws. Rowman \& Littlefield.

Isenmann, Eberhard. 2012. Die deutsche Stadt im Mittelalter 1150-1550, Stadtgestalt, Recht, Verfassung, Stadtregiment, Kirche, Gesellschaft, Wirtschaft. Berlin: Böhlau.

Jäckle, Sebastian, and Pascal D. König. 2017. "The Dark Side of the German 'Welcome Culture': Investigating the Causes behind Attacks on Refugees in 2015." West European Politics 40 (2): 223-51. https://doi.org/10.1080/01402382.2016.1215614.

Jedwab, Remi, Noel D. Johnson, and Mark Koyama. 2019. "Negative Shocks and Mass Persecutions: Evidence from the Black Death." Journal of Economic Growth 24: 345-95. https://doi.org/10.1007/s10887-019-09167-1.

Johnson, Noel D., and Mark Koyama. 2019. Persecution and Toleration: The Long Road to Religious Freedom. Cambridge: Cambridge University Press.

Jones, Emily, and Alexandra O Zeitz. 2019. "Regulatory Convergence in the Financial Periphery: How Interdependence Shapes Regulators' Decisions.” International Studies Quarterly 63 (4): 908-22. https://doi.org/10.1093/isq/sqz068.

Jorgenson, Andrew K. 2009. "Political-Economic Integration, Industrial Pollution and Human Health: A Panel Study of Less-Developed Countries, 1980-2000.” International Sociology 24 (1): 115-43. https://doi.org/10.1177/0268580908099156. 
Jorgenson, Andrew K. 2010. "World-Economic Integration, Supply Depots, and Environmental Degradation: A Study of Ecologically Unequal Exchange, Foreign Investment Dependence, and Deforestation in Less Developed Countries." Critical Sociology 36 (3): 453-77. https://doi.org/10.1177/0896920510365204.

Karch, Andrew, Sean C. Nicholson-Crotty, Neal D. Woods, and Ann O’M. Bowman. 2016. "Policy Diffusion and the Pro-Innovation Bias." Political Research Quarterly 69 (1): 83 95. https://doi.org/10.1177/1065912915622289.

Kim, Junghack, Bruce D. McDonald, and Jooho Lee. 2018. "The Nexus of State and Local Capacity in Vertical Policy Diffusion." The American Review of Public Administration 48 (2): 188-200. https://doi.org/10.1177/0275074016675966.

Koenig, Matthias, and Julian Dierkes. 2011. "Conflict in the World Polity - Neo-Institutional Perspectives.” Acta Sociologica 54 (1): 5-25. https://doi.org/10.1177/0001699310392600.

Koyama, Mark. 2010. “The Political Economy of Expulsion: The Regulation of Jewish Moneylending in Medieval England." Constitutional Political Economy 21 (4): 374-406. https://doi.org/10.1007/s10602-010-9087-3.

Kreindler, Gabriel E., and H. Peyton Young. 2014. "Rapid Innovation Diffusion in Social Networks." Proceedings of the National Academy of Sciences 111 (suppl. 3): 10881-88. https://doi.org/10.1073/pnas.1400842111.

Kreutz, Bernhard. 2005. Städtebünde und Städtenetz am Mittelrhein im 13. und 14. Jahrhundert. Trierer historische Forschungen 54. Trier: Kliomedia.

Kroneberg, Clemens, and Andreas Wimmer. 2012. "Struggling over the Boundaries of Belonging: A Formal Model of Nation Building, Ethnic Closure, and Populism." American Journal of Sociology 118 (1): 176-230. https://doi.org/10.1086/666671.

LaFree, Gary, Min Xie, and Aila M. Matanock. 2018. "The Contagious Diffusion of Worldwide Terrorism: Is It Less Common Than We Might Think?’ Studies in Conflict \& Terrorism 41 (4): 261-80. https://doi.org/10.1080/1057610X.2017.1290428.

Lamont, Michèle. 2000. The Dignity of Working Men: Morality and the Boundaries of Race, Class, and Immigration. Harvard University Press. http://books.google.com/books?hl=en\&lr=\&id=ehXs95d-BU4C\&pgis=1.

Leffel, Benjamin. 2022. "Toward Global Urban Climate Mitigation: Linking National and Polycentric Systems of Environmental Change." Sociology of Development 8 (1): 11137. https://doi.org/10.1525/sod.2021.0018.

Lemoine, Nathan P. 2019. "Moving beyond Noninformative Priors: Why and How to Choose Weakly Informative Priors in Bayesian Analyses.” Oikos 128 (7): 912-28. https://doi.org/10.1111/oik.05985.

Levi, Margaret. 1981. "The Predatory Theory of Rule.” Politics \& Society 10 (4): 431-65. https://doi.org/10.1177/003232928101000403.

Linebarger, Christopher. 2016. "Dangerous Lessons: Rebel Learning and Mobilization in the International System.” Journal of Peace Research 53 (5): 633-47. https://doi.org/10.1177/0022343316653462.

Luzzati, Michele. 1999. "Zwischen Akzeptanz und Ablehnung: Lucca und die Juden vom 9. bis zum 16. Jahrhundert." In Judenvertreibungen in Mittelalter und früher Neuzeit, edited by Friedhelm Burgard, Alfred Haverkamp, and Gerd Mentgen, 23-36. Hannover: Hahn.

Maimon, Ayre, Mordechai Breuer, and Yaakov Guggenheim. 1987. Germania Judaica, Band III: 1350-1519. Tübingen: Mohr Siebeck. 
McAdam, Doug, Sidney Tarrow, and Charles Tilly. 2001. Dynamics of Contention. New York: Cambridge University Press.

McElreath, Richard. 2016. Statistical Rethinking: A Bayesian Course with Examples in R and Stan. Boca Raton, FL: Chapman \& Hall/CRC Press.

Meyer, John W., John Boli, George M. Thomas, and Francisco O. Ramirez. 1997. "World Society and the Nation-State." American Journal of Sociology 103 (1): 144-81. http://www.jstor.org/stable/10.1086/231174.

Mitchell, Joshua L., and Brendan Toner. 2016. "Exploring the Foundations of US State-Level Anti-Sharia Initiatives." Politics and Religion 9 (4): 720-43. https://doi.org/10.1017/S1755048316000419.

Müller, Jörg R. 2002. "Judenverfolgungen und -vertreibungen zwischen Nordsee und Südalpen im hohen und späten Mittelalter." In Geschichte der Juden im Mittelalter von der Nordsee bis zu den Südalpen, Vol. 1: Kommentarband, edited by Alfred Haverkamp, 189-222. Hannover: Hahn.

Myers, Daniel J. 2000. "The Diffusion of Collective Violence: Infectiousness, Susceptibility, and Mass Media Networks.” American Journal of Sociology 106 (1): 173-208. https://doi.org/10.1086/303110.

—. 2010. "Violent Protest and Heterogeneous Diffusion Processes: The Spread of U.S. Racial Rioting From 1964 to 1971." Mobilization: An International Quarterly 15 (3): 289-321. https://doi.org/10.17813/maiq.15.3.f16204108631474v.

Nelson, Laura K. 2021. "Cycles of Conflict, a Century of Continuity: The Impact of Persistent Place-Based Political Logics on Social Movement Strategy.” American Journal of Sociology 127 (1): 1-59. https://doi.org/10.1086/714915.

Nirenberg, David. 1996. Communities of Violence: Persecution of Minorities in the Middle Ages. Princeton: Princeton University Press. . 2009. "Was There Race before Modernity? The Example of 'Jewish' Blood in Late Medieval Spain.” In The Origins of Racism in the West, edited by Miriam Eliav-Feldon, Benjamin Isaac, and Joseph Ziegler, 232-64. Cambridge: Cambridge University Press.

Olar, Roman-Gabriel. 2019. "Do They Know Something We Don't? Diffusion of Repression in Authoritarian Regimes." Journal of Peace Research 56 (5): 667-81. https://doi.org/10.1177/0022343318822718.

Olson, Mancur. 1993. “Dictatorship, Democracy, and Development.” American Political Science Review 87 (3): 567-76. http://www.jstor.org/stable/10.2307/2938736.

Pepinsky, Thomas B., Sara Wallace Goodman, and Conrad Ziller. 2020. "Does Proximity to Nazi Concentration Camps Make Germans Intolerant? Modeling Spatial Heterogeneity and Historical Persistence.” SSRN Scholarly Paper ID 3547321. Rochester, NY: Social Science Research Network. https://papers.ssrn.com/abstract=3547321.

Quisumbing King, Katrina. 2019. "Recentering U.S. Empire: A Structural Perspective on the Color Line." Sociology of Race and Ethnicity 5 (1): 11-25. https://doi.org/10.1177/2332649218761977.

Ray, Victor. 2019. “A Theory of Racialized Organizations.” American Sociological Review 84 (1): 26-53. https://doi.org/10.1177/0003122418822335.

Reagans, Ray, and Bill McEvily. 2003. "Network Structure and Knowledge Transfer: The Effects of Cohesion and Range." Administrative Science Quarterly 48 (2): 240-67. http://www.jstor.org/stable/3556658. 
Ries, Rotraud. 1995. "German Territorial Princes and the Jews." In In and Out of the Ghetto: Jewish-Gentile Relations in Late Medieval and Early Modern Germany, edited by R. Pochia Hsia and Hartmut Lehmann, 215-46. New York: Cambridge University Press.

Rubin, Jared. 2014. "Printing and Protestants: An Empirical Test of the Role of Printing in the Reformation." Review of Economics \& Statistics 96 (2): 270-86. https://doi.org/10.1162/REST_a_00368.

Rubin, Miri. 1995. "Imagining the Jew: The Late Medieval Eucharistic Discourse." In In and Out of the Ghetto: Jewish-Gentile Relations in Late Medieval and Early Modern Germany, edited by R. Po-chia Hsia and Hartmut Lehmann, 177-208. New York: Cambridge University Press. 1999. Gentile Tales: The Narrative Assault on Late Medieval Jews. New Haven: Yale University Press.

Rydgren, Jens. 2005. "Is Extreme Right-Wing Populism Contagious? Explaining the Emergence of a New Party Family.” European Journal of Political Research 44 (3): 413-37. https://doi.org/10.1111/j.1475-6765.2005.00233.x.

Sánchez-Rivera, R. 2021. "The Making of 'La Gran Familia Mexicana': Eugenics, Gender, and Sexuality in Mexico.” Journal of Historical Sociology 34 (1): 161-85. https://doi.org/10.1111/johs.12308.

Sassen, Saskia. 2006. Cities in a World Economy. Thousand Oaks, CA: Pine Forge Press.

- 2014. Expulsions: Brutality and Complexity in the Global Economy. Cambridge, Massachusetts: The Belknap Press of Harvard University Press.

Scholl, Christian. 2012. "Juden und Städtebünde. Annäherungen an ein komplexes Beziehungsgeflecht." In Pro multis beneficiis. Festschrift für Friedhelm Burgard. Forschungen zur Geschichte der Juden und des Trierer Raums, edited by Sigrid Hirbodian, Christian Jörg, Sabine Klapp, and Jörg R. Müller, 111-27. Trierer historische Forschungen 68. Trier: Kliomedia. . 2015. "Die Rolle jüdischer Finanziers bei reichsstädtischen Expansionsbestrebungen im späten Mittelalter.” Aschkenas 25 (1): 161-79. https://doi.org/10.1515/asch-2015-0006.

Shipan, Charles R., and Craig Volden. 2008. "The Mechanisms of Policy Diffusion." American Journal of Political Science 52 (4): 840-57. https://doi.org/10.1111/j.15405907.2008.00346.x.

Sikkink, Kathryn. 2014. "Latin American Countries as Norm Protagonists of the Idea of International Human Rights." Global Governance 20 (3): 389-404. https://www.jstor.org/stable/24526221.

Snyder, David, and Edward L. Kick. 1979. "Structural Position in the World System and Economic Growth , 1955-1970: A Multiple-Network Analysis of Transnational Interactions." American Journal of Sociology 84 (5): 1096-1126. http://www.jstor.org/stable/2778218.

Stacey, Robert C. 1992. "The Conversion of Jews to Christianity in Thirteenth-Century England." Speculum 67 (2): 263-83. . 1997. "Parliamentary Negotiation and the Expulsion of Jews from England." In Thirteenth Century England VI, edited by Michael Prestwich, Richard Britnell, and Robin Frame, 77-101. Woodbridge, Suffolk: The Boydell Press.

Stan Development Team. 2018a. "Stan Development Repository: Prior Choice Recommendations.” May 4, 2018. https://github.com/stan-dev/stan/wiki/Prior-ChoiceRecommendations. 
. 2018b. "Rstanarm: Bayesian Applied Regression Modeling via Stan.” https://CRAN.Rproject.org/package $=$ rstanarm.

Stow, Kenneth R. 1992. Alienated Minority: The Jews of Medieval Latin Europe. Cambridge, MA: Harvard University Press.

. 2001. "Conversion, Apostasy, and Apprehensiveness: Emicho of Floheim and the Fear of Jews in the Twelfth Century." Speculum 76 (4): 911-33.

https://doi.org/10.2307/2903615.

- 2007. Popes, Church, and Jews in the Middle Ages: Confrontation and Response. Burlington, VT: Ashgate.

Strang, David. 1991. "Adding Social Structure to Diffusion Models: An Event History Framework." Sociological Methods \& Research 19 (3): 324-53. https://doi.org/10.1177/0049124191019003003.

Strang, David, and Michael W. Macy. 2001. "In Search of Excellence: Fads, Success Stories, and Adaptive Emulation.” American Journal of Sociology 107 (1): 147-82. https://doi.org/10.1086/323039.

Strang, David, and Nancy Brandon Tuma. 1993. "Spatial and Temporal Heterogeneity in Diffusion." American Journal of Sociology 99 (3): 614-39. https://doi.org/10.1086/230318.

Tilly, Charles. 1998. Durable Inequality. Berkeley: University of California Press.

Toch, Michael. 2003. Peasants and Jews in Medieval Germany. Burlington, VT: Ashgate.

Tolnay, Stewart E., Glenn Deane, and E. M. Beck. 1996. "Vicarious Violence: Spatial Effects on Southern Lynchings, 1890-1919.” American Journal of Sociology 102 (3): 788-815. https://doi.org/10.1086/230997.

Tschantret, Joshua. 2019. "Cleansing the Caliphate: Insurgent Violence against Sexual Minorities." International Studies Quarterly 62 (2): 260-73. https://doi.org/10.1093/isq/sqx074.

Tyers, Matt. 2017. "Riverdist: River Network Distance Computation and Applications.” R. https://cran.r-project.org/package=riverdist.

Velasco, Kristopher. 2018. "Human Rights INGOs, LGBT INGOs, and LGBT Policy Diffusion, 1991-2015." Social Forces 97 (1): 377-404. https://doi.org/10.1093/sf/soy030.

Velasco, Kristopher, and Pamela Paxton. 2022. "Deconstructed and Constructive Logics: Explaining Inclusive Language Change in Queer Nonprofits, 1998-2016.” American Journal of Sociology 127 (4): 1267-1310. https://doi.org/10.1086/718279.

Volden, Craig, Michael M. Ting, and Daniel P. Carpenter. 2008. "A Formal Model of Learning and Policy Diffusion.” American Political Science Review 102 (03): 319-32. https://doi.org/10.1017/S0003055408080271.

Watts, Duncan J., and Peter Sheridan Dodds. 2007. "Influentials, Networks, and Public Opinion Formation." Journal of Consumer Research 34 (4): 441-58. https://doi.org/10.1086/518527.

Watts, Duncan J., and Steven H. Strogatz. 1998. "Collective Dynamics of 'Small-World' Networks.” Nature 393 (6684): 440-42. https://doi.org/10.1038/30918.

Weber, Max. 1964. The Theory of Social and Economic Organization. Translated by Talcott Parsons. 3rd ed. New York: The Free Press.

Weeda, Claire. 2014. "Ethnic Identification and Stereotypes in Western Europe, circa 11001300.” History Compass 7: 586-606. https://doi.org/10.1111/hic3.12174. 
Weeden, Kim A. 2002. "Why Do Some Occupations Pay More than Others? Social Closure and Earnings Inequality in the United States.” American Journal of Sociology 108 (1): 55101. https://doi.org/10.1086/344121.

Wenninger, Markus J. 1981. Man bedarf keiner Juden mehr. Ursachen und Hintergründe ihrer Vertreibung aus den deutschen Reichsstädten im 15. Jahrhundert. Vienna: Böhlaus.

—. 2012. "Geld und Politik. Spezialprivilegien für jüdische Großbankiers des 14. Jahrhunderts im Südostalpenraum." Aschkenas 20 (2): 305-424. https://doi.org/10.1515/asch-2010-0012.

Weyland, Kurt. 2010. "The Diffusion of Regime Contention in European Democratization, 1830-1940." Comparative Political Studies 43 (8-9): 1148-76. https://doi.org/10.1177/0010414010370439. 2017. "Autocratic Diffusion and Cooperation: The Impact of Interests vs. Ideology." Democratization 24 (7): 1235-52. https://doi.org/10.1080/13510347.2017.1307823.

White, Harrison C. 1965. "Notes on the Constituents of Social Structure." Lecture.

Wimmer, Andreas. 2021. "Domains of Diffusion: How Culture and Institutions Travel around the World and with What Consequences.” American Journal of Sociology 126 (6): 13891438. https://doi.org/10.1086/714273.

$\mathrm{Xu}$, Hongwei, and Geng Tian. 2020. "Is Lying Contagious? Spatial Diffusion of High-Yield 'Satellites' during China's Great Leap Forward.” American Journal of Sociology 126 (3): 632-72. https://doi.org/10.1086/712407. 


\section{SUPPLEMENTARY MATERIALS}

Supplementary materials for this paper include: (A) a description of the geospatial data and calculations, (B) additional Bayesian event history analyses referred to in the main paper, and $(\mathrm{C})$ details about the Bayesian event history model parameters and statistics.

\section{APPENDIX A. DATA COLLECTION}

This study relies mostly on data contained in Geschichte der Juden im Mittelalter von der Nordsee bis zu den Südalpen (Haverkamp 2002). This three-volume work was produced by a team of historians, led by Alfred Haverkamp, under a grant from the German Research Foundation (Deutsche Forschungsgemeinschaft) to complete a historiographical summary and update on the history of Jews in the region of the Meuse and Rhine Rivers, 1000-1520 CE. The project revisited the first efforts to do so, begun a century previously and published in three volumes as Germania Judaica.

\section{Jewish settlement and persecutions}

The second volume of Geschichte der Juden is a city catalog that systematically describes Jewish settlement, persecutions, city dominion, and city infrastructure in numbered lists, annotated with sources. City dominion and infrastructure data came from the Deutsches Städtebuch (Keyser and Stoob 1939), another multivolume work of historical detail on regional development. I digitized the city catalog through data entry. As written, the catalog assigns dates in periods, since it can be difficult to date medieval histories to specific years. To convert these periods to annual observations, I follow a few procedures. When settlement dates are known, I include all years between a first known year and a last known year, excepting any known disruptions due to persecutions or expulsions. Where arrival is uncertain, if Jewish settlement in a town is only apparent because of a pogrom or expulsion, I add the three prior years. If arrival date is uncertain but settlement is evidenced within a period, such as through the undated erection of a synagogue, I use the first year of the period. For expulsions, I discard possible expulsions with "uncertain" evidence and expulsions without any dating to a year or range of years. Ranges occur when dating can be made relative to other dated events or when it is unclear what system a primary source uses to number months. In medieval Europe, some counted the new year and first month from December 25, and others counted from March 25. For expulsions dated to a range of years, I code the expulsion to the first year given. I also discard 
unsuccessful/incomplete expulsions that were policy only and rescinded or not enforced later. I follow the same procedures to record pogroms and therefore create sums of prior persecutions and expulsions.

\section{Domestic conditions}

To assign city dominion, I recorded a dataset of dominion as spells for each city, with start and end years and dominion parties. From the dominion parties, I coded whether dominion was held (or shared) by the emperor, princes, bishops, archbishops, and more, or whether the city held rights of self-government and was therefore a free city. I transformed this spell-based data into an annual table of the specific parties and party types for each year for each city. From this I can construct the counts of expulsions under different types of governors.

To measure city economic and political institutions, I assign their presence for all years in a period in which they are evidenced, or from the year of their first evidence, and all successive years, unless it is recorded that they were changed, removed, or otherwise no longer existent.

For Jewish community development, I similarly assign the presence of a cemetery, mikveh, or Jewish quarter for all years in a period in which they are evidenced, or from the year of their first evidence, and all successive years, unless it is recorded that they were destroyed or otherwise no longer existent. I include Jewish quarters in this list because they were originally a requested feature of Jewish urban life, to facilitate keeping the Sabbath and to make space more defensible (Haverkamp 1995).

For membership in regional alliances, I recreated Distler's (2006) table of regional alliances. I reorganized it from treaty-based observations with a list of parties to treaty-party observations that list a single party, a single year, and a single treaty. From here I could code whether each city participated in an alliance treaty in a year (and how many) and calculate how many prior alliances the city had participated in.

\section{Spatial relationships}

The first volume of Geschichte der Juden, and one of its improvements over Germania Judaica, contains maps produced in the early cartographic software Freehand. The digital files and their metadata are not available, nearly 20 years after their production. I digitized and georeferenced the maps in QGIS to gather city locations; duplicate names and otherwise-lost locations of historical cities make these maps vital for any spatial analyses. The maps appear to be created using the German Gauss-Krüger projection. For this study, the data were reprojected 
to the Lambert azimuthal equal area projection for Europe based on the European Terrestrial System 1989 (ETRS89), code EPSG:3035 (unit: meters). A Lambert azimuthal equal area projection preserves both distance and direction better than other map projections. The continentscale projection is necessary because the study area is geographically large. Because distance accuracy and intelligibility are vital for this analysis, EPSG:3035 is the best map projection choice. All spatial calculations are performed using this projection and transformed into kilometers.

I obtain distances between cities along river and road travel routes. Bossak and Welford (2015) shared the data they collected of pilgrimage routes. I transformed these routes, composed of geolocated city sequences, into segmented lines. For water-based travel routes, I downloaded the Natural Earth rivers and lake centerlines (10 meter resolution) with scale ranks. Prior to spatial calculations, I preprocessed the pilgrimate routes and river courses in QGIS. I completed a spatial dissolve, added vertices at intersections, and snapped the city locations onto the network at the nearest route. Then I used the riverdist R package (Tyers 2017) and its riverdistancemat function to calculate distances between each city and all other cities along the network. For accuracy, since not all cities were located close to a transit route, I augmented the inter-city distances by adding in the distances between actual city locations and their network-snapped locations.

Hypotheses indicated that expelling cities should be closer to each other than what random spatial distribution of expulsions would predict. Investigating spatial autocorrelation of expulsions is also a pre-regression best practice (Kelly 2019). The unit of analysis here is cities, which are located at spatial points. First, I performed a Monte Carlo test of average nearest neighbors. I simulated 1000 random assignments of whether a city ever expelled, maintaining the overall number of expelling cities within each simulation. Figure A1 shows the outcomes of the simulations compared to the observed average distance to a city's nearest neighbor. The observed average nearest expelling neighbor is 28.99 kilometers away. The observed distance is below $83.8 \%$ of the simulated neighbor distances. This does not provide evidence that the distribution of expulsions is non-random. Among non-expelling cities, the observed average nearest neighbor is 13.56 kilometers away. In these simulations, the observed distance is below $68.6 \%$ of the simulated neighbor distances. We cannot conclude that the distribution of nonexpulsions is non-random. 


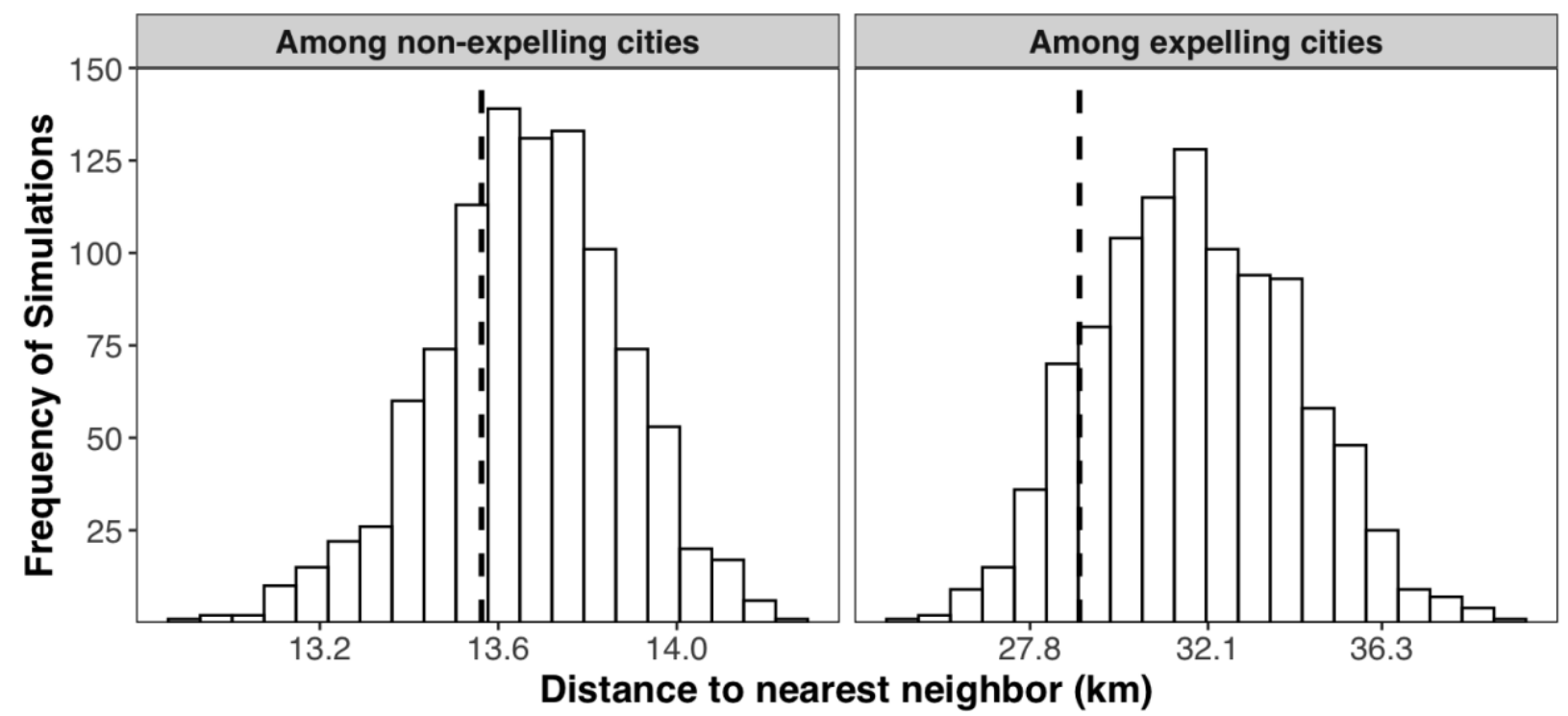

Figure A1. Comparing the Observed and Simulated Distributions of First Nearest Neighbors Note. Dotted lines are the observed mean distance to the nearest same-outcome neighbor.

A major goal of this paper is to examine the temporal proximity of expulsions, not only spatial proximity. With this in mind, it is sensible to redo the Monte Carlo test of average nearest neighbors pooled within temporal subsets, rather than pooled across the whole study period. To split this into even and manageable time frames, I divided into 5 periods of 27 years. This is a little unwieldy, but the periods match up rather well to potential waves of expulsions: preCouncil of Constance, post-Council of Constance, the mid-century lull in expulsions (which also coincides with the time of Nicholas of Cusa, antisemitic traveling emissary of the pope, mentioned in the main text), the late-century uptick in political conflict and the rise of the princes, and the urban rebellions as well as revivals on the eve of the Reformation. Figures A2 and A3 illustrate the simulated distributions for expelling cities and non-expelling cities, respectively, within temporal subsamples; table A1 logs the distribution comparisons. 
Table A1. Observed Distance (km) to First Nearest Neighbors and Percentile Rank among 1000 Simulated Distributions, by Period

\begin{tabular}{lllll}
\hline Period & Expelling cities & & \multicolumn{2}{l}{ Non-expelling cities } \\
& Observed distance & Percentile & Observed distance & Percentile \\
\hline $1385-1411$ & 83.105 & 10.1 & 15.403 & 17.8 \\
$1412-1438$ & 63.621 & 54.3 & 14.500 & 23.5 \\
$1439-1465$ & 51.808 & 11.1 & 13.241 & 46.6 \\
$1466-1492$ & 56.177 & 89.1 & 15.519 & 68.6 \\
$1493-1520$ & 46.267 & 54.8 & 15.604 & 40.2 \\
\hline
\end{tabular}

For expelling cities, the observed values are not significantly different from the simulated values. The observed average nearest expelling neighbor ranges from 46.27 kilometers away to 83.11 kilometers away. The observed distance is closer than the simulated neighbor distances in 1385-1411 and in 1439-1465, spot on in 1412-1438 and 1493-1520, and farther apart in 14661492. Besides relative values, the actual distances are informative. Simulated nearest neighbors for 1385-1411 are actually very far apart, with a range much higher than the other periods. Though the observed value is most different from the simulated ones, it is actually farther away than at any other period. On the contrary, the simulated as well as observed nearest neighbor distances for non-expellers remain essentially steady across the time periods. Nothing observed is unusual compared to the simulations. These values generally show a left-side tail, which makes sense because the actual distribution is that some cities were in dense areas, but not the majority of them. All in all, this is not strong evidence that the distribution of expulsions is nonrandom, but it does leave open that the distribution might change over time. The shrink in the simulated distances among expellers, and the variation in difference between the observed and simulated distances is some small evidence of spatio-temporal relationships, but not of a direct relationship just between these three factors. I argue that other factors, which may also have spatial and temporal variation, are what provide the link. 


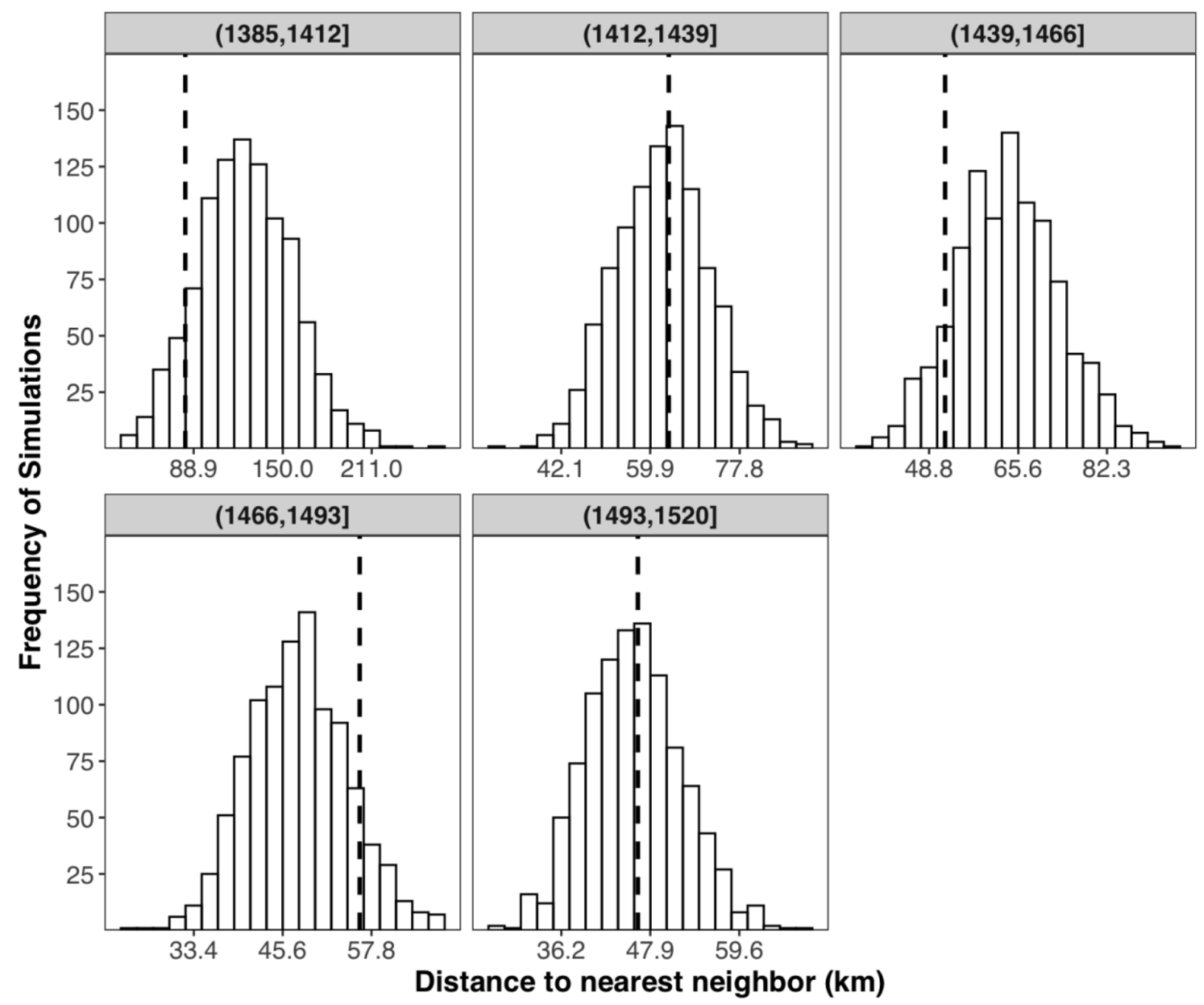

Figure A2. Comparing the Observed and Simulated Distributions of First Nearest Neighbors for Cities that Expelled across Five Year Subsets

Note. Dotted lines are the observed mean distance to the nearest same-outcome neighbor. 


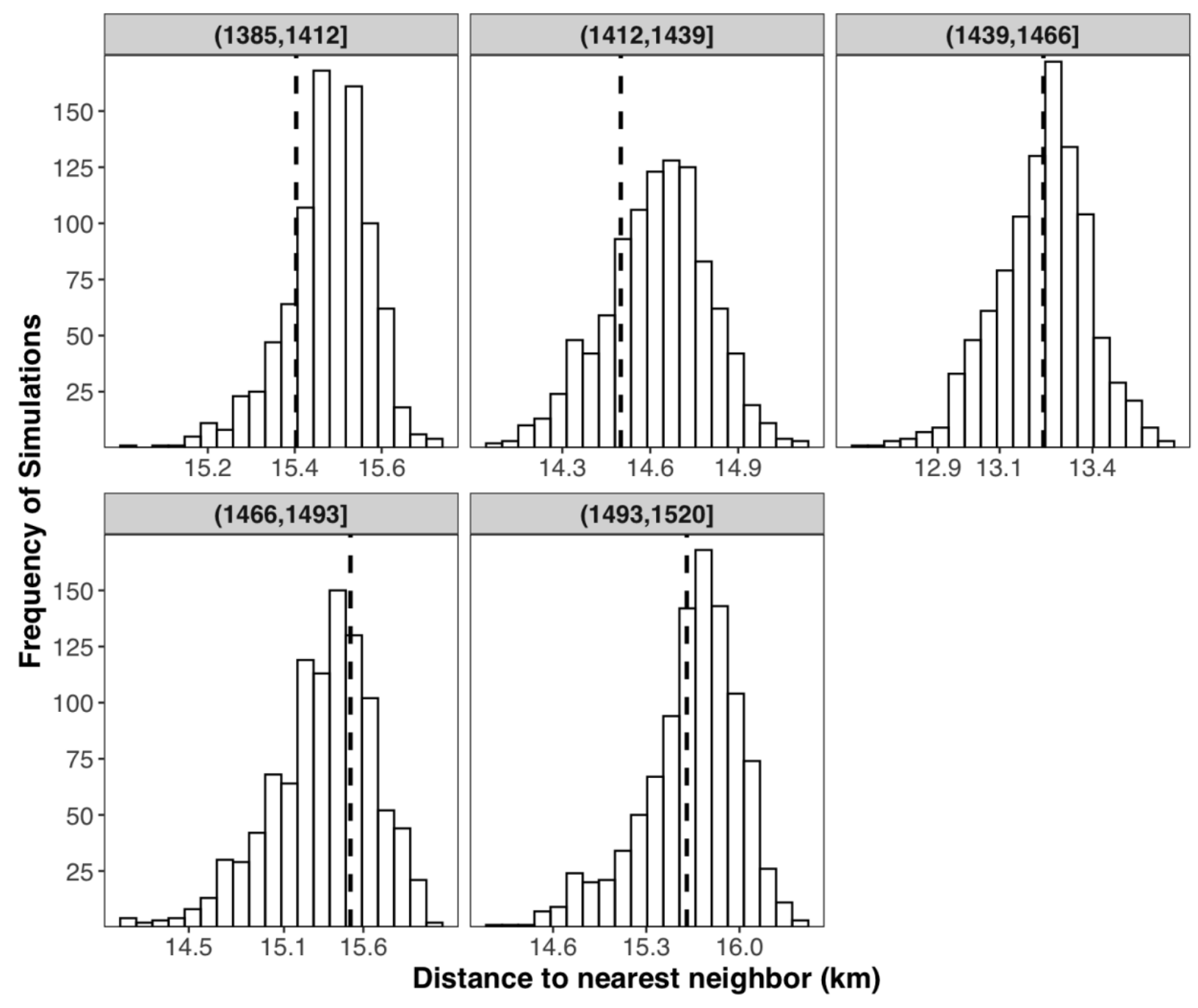

Figure A3. Comparing the Observed and Simulated Distributions of First Nearest Neighbors for Cities that Did Not Expel across Five Year Subsets

Note. Dotted lines are the observed mean distance to the nearest same-outcome neighbor.

Moran's $i$ is used to measure spatial autocorrelation (Tiefelsdorf 2000) when the units of analysis are spatial regions. Although this is not the case, creating Thiessen polygons, which position each city as the centroid of a polygon within a contiguous plane of polygons across the bounded study area, enables me to reexamine spatial autocorrelation using this measure. Once again, I simulated the distribution of expulsions, this time among Theissen polygons. The distribution of expulsion is more clustered than expected, both by using Thiessen polygon contiguous neighbors (500 simulations, $i=0.060, p<0.01$ ) and by using a distance band of $60 \mathrm{~km}$ 
between Thiessen polygon centroids (500 simulations, $i=0.064, p<0.01$ ). However, the Moran's $i$ statistics are substantively indistinguishable from 0 . These results are related to the fact that there are very few expulsions. Even if they are more clustered than might be expected, they are really not very clustered.

In parallel to the periodized average nearest neighbor tests, and based in the same recognition that temporal proximity is an important consideration in spatial autocorrelation in this study, I conducted further Monte Carlo tests of Moran's $I$ by the five periods, simulating the distribution of expulsions 500 times each. Table A2 summarizes the results. The evidence here does indicate that spatial autocorrelation may be a concern during the latter part of the study period, both as assessed using contiguous neighbors and using a $60 \mathrm{~km}$ distance band. For both 1466-1492 and 1493-1520, the observed distribution of expulsions was significantly more spatially clustered than in simulated distributions. However, the absolute value of the Moran's $I$ for these two periods is still effectively 0 , indicating very little clustering. I do not believe that the spatial autocorrelation is enough to warrant additional statistical techniques, beyond the spatial lags used in the main analyses for specific substantive and theoretical reasons.

Table A2. Monte Carlo Tests of Moran's I, by Period

\begin{tabular}{lllll}
\hline Period & \multicolumn{2}{l}{ Contiguous neighbors } & $60 \mathrm{~km}$ band & \\
& Moran's $I$ & $\mathrm{p}$ & Moran's $\mathrm{p}$ & 0.174 \\
\hline $1385-1411$ & 0.006 & 0.405 & 0.015 & 0.347 \\
$1412-1438$ & 0.046 & 0.056 & 0.001 & 0.537 \\
$1439-1465$ & 0.026 & 0.182 & -0.007 & $0.008^{* *}$ \\
$1466-1492$ & 0.058 & $0.044^{*}$ & 0.068 & $0.016^{*}$ \\
$1493-1520$ & 0.056 & $0.050^{*}$ & 0.055 & \\
\hline
\end{tabular}

Note. $* \mathrm{p}<0.05 ; * * \mathrm{p}<0.01$ 


\section{APPENDIX B. BAYESIAN EVENT-HISTORY ANALYSES: ROBUSTNESS}

To test my trust in the main results, I completed series of additional analyses as robustness checks. First, I examined whether economic shocks, as a result of climate variation and the resulting fluctuation in agricultural production, contributed to patterns in expulsions. Second, I revisited the main results and adjusted the time lag from 10 years to 5 years and to 20 years.

Other research has concluded that poor harvests (Behringer 1995, 1999; Oster 2004) led to violent scapegoating of Jewish communities (Anderson, Johnson, and Koyama 2017) in medieval and early modern Europe. Such a pattern might hide within the temporal and spatiotemporal measures I have used, as it would have both temporal and geographic dimensions. To rule out this alternative, I imitate how Anderson, Johnson, and Koyama (2017) investigate poor harvests, using annual growing season (March-September) temperatures. I rely on the Community Climate Systems Model 4.0 (CCSM4.0) monthly climate retrodictions (Landrum et al. 2012) produced by the U.S. National Center for Atmospheric Research for 8001800CE. Unlike the Guiot, Corona, and ESCARSEL Members (Guiot, Corona, and Members 2010) retrodictions some use, the CCSM4.0 retrodictions cover the entire European continent, including the Alps. I extract the mean monthly temperatures (Celsius) for each city for March through September for each year and average them, then lag the temperature measures one year $(\min =6.95, \max =18.88$, mean=13.99, median=14.11, $\mathrm{sd}=1.26)$. As with other continuous variables, I rescale the temperature lags to a distribution centered on 0 with a standard deviation of 0.5 prior to including this variable in the model. Reanalysis with growing season temperature variation (table B1) does not change the main results, and there is no relationship between temperature and expulsion.

As a last step, I returned to the original model specifications. In the main analyses, diffusion measures were calculated by using counts of expulsions in the prior 10 years. I recalculated the diffusion measures for two alternative spans: 5 years and 20 years. Table B2 displays descriptive statistics for these variables. I reestimated model 4 using each of these variations (see table B3). Using a 5-year span, the temporal and spatial diffusion effects disappear, except distance from Constance. Instead, the 15-year time period dummies soak up the temporal variation in expulsions. One change using the 20 -year span is that in model B3, the 
spatial suppression effect seen originally only among free and imperial cities is evident for episcopal cities as well. Ten years appears to be a sensitive enough temporal lag.

Table B1. Results of Reanalysis for Climactic Impacts

\begin{tabular}{lcc}
\hline & & (B1) \\
\hline Growing Season Temperature & -0.29 & SD \\
Dif2 (10-yr, episcopal) & -0.49 & 0.26 \\
Dif2 (10-yr, free/imperial) & -0.81 & 0.4 \\
Dif3 (10-yr, episcopal) & -0.97 & 2.98 \\
Dif3 (10-yr, free/imperial) & 0.86 & 0.48 \\
Dif3 (episc.) * episc. & 0.8 & 2.99 \\
Dif3 (free/imp.) * free/imp. & 0.29 & 0.44 \\
Km to Constance & -1.1 & 0.43 \\
Episcopal & 0.52 & 0.9 \\
Free or imperial & -0.07 & 0.65 \\
Prince & -0.13 & 0.52 \\
Count of dominion parties & -0.22 & 0.43 \\
Schöffen & -1.29 & 0.71 \\
Market development & 0.35 & 0.36 \\
Foreign moneylenders & 1.56 & 0.64 \\
Mint & 1.53 & 0.47 \\
Jewish community development & 1.41 & 0.44 \\
Total previous persecutions & -0.28 & 0.22 \\
Total previous expulsions & 0.76 & 0.31 \\
Global Intercept & -10.17 & 1.15 \\
Settlement Random Effects & & \\
Log-posterior & & -2979.05 \\
\hline Note. Continus & \\
\hline
\end{tabular}

Note. Continuous variables were scaled prior to estimation to the distribution mean $=0, \mathrm{sd}=0.5$. 
Table B2. Descriptive Statistics: Diffusion Measures for Alternate Time Lags

\begin{tabular}{lccccc}
\hline & Min & Max & Mean & Median & St. Dev. \\
\hline 5 Years & & & & & \\
\hline Dif2 (episcopal) & 0 & 0.99 & 0.02 & 0 & 0.07 \\
Dif2 (free/imperial) & 0 & 4.78 & 0.03 & 0 & 0.16 \\
Dif3 (episcopal) & 0 & 4 & 0.28 & 0 & 0.67 \\
Dif3 (free/imperial) & 0 & 7 & 0.27 & 0 & 0.93 \\
\hline 20 years & & & & & \\
\hline Dif2 (episcopal) & 0 & 4.97 & 0.11 & 0 & 0.38 \\
Dif2 (free/imperial) & 0 & 1.37 & 0.09 & 0 & 0.19 \\
Dif3 (episcopal) & 0 & 7 & 0.99 & 0 & 1.94 \\
Dif3 (free/imperial) & 0 & 14 & 0.95 & 0 & 2.73 \\
\hline
\end{tabular}


Table B3. Results of Reanalysis with Five-year and Twenty-year Lags

\begin{tabular}{|c|c|c|c|c|}
\hline & (B2) & & (B3) & \\
\hline & Mean & SD & Mean & SD \\
\hline Dif2 (episcopal) & 0.07 & 0.51 & -1.49 & 0.87 \\
\hline Dif2 (free/imperial) & -0.35 & 0.29 & -0.86 & 0.45 \\
\hline Dif3 (episcopal) & -1.07 & 3.02 & -0.85 & 2.94 \\
\hline Dif3 (free/imperial) & 0.38 & 0.4 & 0.99 & 0.55 \\
\hline Dif3 (episc.) * episc. & 0.5 & 3.02 & 1.44 & 2.96 \\
\hline Dif3 (free/imp.) * free/imp. & 0.13 & 0.38 & 0.01 & 0.48 \\
\hline Km to Constance & -1.08 & 0.43 & -1.11 & 0.42 \\
\hline Episcopal & 0.22 & 0.82 & 0.86 & 0.94 \\
\hline Free or imperial & 0.08 & 0.61 & 0.12 & 0.65 \\
\hline Prince & -0.15 & 0.51 & -0.1 & 0.51 \\
\hline Count of dominion parties & -0.21 & 0.41 & -0.24 & 0.42 \\
\hline Schöffen & -1.19 & 0.67 & -1.16 & 0.68 \\
\hline Market development & 0.34 & 0.35 & 0.29 & 0.35 \\
\hline Foreign moneylenders & 1.58 & 0.61 & 1.52 & 0.61 \\
\hline Mint & 1.52 & 0.46 & 1.49 & 0.46 \\
\hline Jewish community development & 1.37 & 0.42 & 1.37 & 0.43 \\
\hline Total previous persecutions & -0.27 & 0.21 & -0.21 & 0.22 \\
\hline Total previous expulsions & 0.78 & 0.3 & 0.79 & 0.3 \\
\hline Global Intercept & -9.88 & 1.09 & -10.4 & 1.16 \\
\hline Settlement Random Effects & Yes & & Yes & \\
\hline Log-posterior & -2985.23 & & -2980.29 & \\
\hline
\end{tabular}

Note. Continuous variables were scaled prior to estimation to the distribution mean $=0, \mathrm{sd}=0.5$. 


\section{APPENDIX C. BAYESIAN EVENT-HISTORY ANALYSES: DETAILS}

The discrete-time event history analysis results in this study were calculated using Markov Chain Monte Carlo Bayesian methods for logistic regression. I use the rstanarm package 2.18.2 (Stan Development Team 2018a) in R (version 3.6.3), which uses the No-U-Turn Sampler (NUTS) Hamiltonian Monte Carlo (HMC) algorithm. I use weakly informative priors (Betancourt 2017; Gelman et al. 2008; McElreath 2016; Stan Development Team 2018b). For the independent variable terms, I choose the Student's t distribution $(\mathrm{df}=7$, scale $=2.5)$, while I use the half-t distribution $(\mathrm{df}=4$, scale $=1)$ for intercept priors. Each model was estimated using five chains of 5,000 iterations, discarding the first 2,500. For each model I report in table $\mathrm{C} 1$ the step size between iterations and the number of divergent transitions (out of total 12,500 for each model). Table C2 lists the effective sample size for each variable for each model, noting whether the potential scale reduction factor $\widehat{\mathcal{R}}$ for each variable is greater than 1.01 (a warning that the chains disagree on estimates) or than 1.05 (a serious sign of unreliable results). Pareto-smoothed importance sampling leave-one-out cross-validation (PSIS-LOO) (Vehtari et al. 2018; Vehtari, Gelman, and Gabry 2017) is the most reliable strategy to assess confidence in Bayesian model results. Unfortunately, PSIS-LOO is computationally intensive for large samples, especially when model specifications are complicated. Instead, I use exact $K$-fold cross-validation. For each model specification, the data are randomly and evenly divided into 10 sub-samples stratified by the 15-year period dummies (maintaining some sense of time-related balance in each subsample) before re-estimating 10 times on nine of the sub-samples. Table C 3 contains $K$-fold expected log predictive densities (ELPDs) and standard errors. All ELPDs are approximately the same, meaning that model selection here is down to theoretical reasons and interpretability.

Table C1. Model Statistics: Step Size and Divergence

\begin{tabular}{llllllllll}
\hline & $(1)$ & $(2)$ & $(3)$ & $(4)$ & $(5)$ & $(6)$ & $(\mathrm{B} 1)$ & (B2) & (B3) \\
\hline $\begin{array}{l}\text { Observations } \\
\begin{array}{l}\text { Step size } \\
\text { tuning }\end{array}\end{array}$ & 36,182 & 36,182 & 36,182 & 36,182 & 36,182 & 36,182 & 36,182 & 36,182 & 36,182 \\
$\begin{array}{l}\text { parameter } \\
\begin{array}{l}\text { Divergent } \\
\text { transitions }\end{array}\end{array}$ & 0.99 & 0.99 & 0.99 & 0.99 & 0.99 & 0.99 & 0.99 & 0.99 & 0.99 \\
\hline
\end{tabular}


Table C2. Model Statistics: Effective Sample Sizes

\begin{tabular}{|c|c|c|c|c|c|c|c|c|c|}
\hline & $(1)$ & $(2)$ & (3) & (4) & $(5)$ & $(6)$ & (B1) & (B2) & (B3) \\
\hline Dif1 & 13125.5 & 5967.47 & 7350.71 & & & & & & \\
\hline Dif2 (any) & & 5783.1 & & & & 14088.93 & & & \\
\hline Dif2 (episcopal) & & & & 8053.78 & 12424.69 & & 17918.65 & 20715.51 & 23338.17 \\
\hline Dif2 (free/imperial) & & & & 10713.76 & 16879.33 & 9823.49 & 13641.75 & 18359.66 & 15357.37 \\
\hline Dif3 (episcopal) & & & & & 25914.16 & & 8639.45 & 10212.07 & 9821.78 \\
\hline Dif3 (free/imperial) & & & & & 16991.77 & & 11283.96 & 14504.29 & 13594.53 \\
\hline Dif3 (episc.) * episc. & & & & 8143.89 & 12406.03 & & 8624.91 & 10168.85 & 10107.13 \\
\hline Dif3 (free/imp.) * free/imp. & & & & 10258.5 & 14303.4 & 10315.08 & 11922.68 & 14136.09 & 13704.85 \\
\hline After Council of Constance & & & 3731.17 & & & & & & \\
\hline Dif $1 *$ After Constance & & & 7368.03 & & & & & & \\
\hline Km to Constance & & & 6449.08 & 7887.1 & 9545.86 & 5929.49 & 6461.72 & 9001.21 & 9866.68 \\
\hline Count of Travel Routes & & 7851.44 & & & & & & & \\
\hline Total Prior Alliance Treaties & 7739.33 & 7640.69 & & & & & & & \\
\hline Temperature & & & & & & & 13352.57 & & \\
\hline Bishop & 9423.29 & 7483.93 & 6615.1 & & & & & & \\
\hline Archbishop & 9637.45 & 7244.81 & 6765.81 & & & & & & \\
\hline Episcopal & & & & 7946.04 & 10862.3 & 7915.42 & 8056.95 & 9413.56 & 8429.44 \\
\hline Free & 9248.72 & 6671.7 & 5526.92 & & & & & & \\
\hline Imperial & 10420.78 & 8602.37 & 7069.42 & & & & & & \\
\hline Free or imperial & & & & 10845.21 & 14417.28 & 10358.52 & 10043.05 & 12331.14 & 12776.66 \\
\hline Prince & 8658.83 & 6862.34 & 5367.83 & 7858.56 & 11429.59 & 7445.58 & 8035.14 & 10567.74 & 10529.63 \\
\hline Count of dominion parties & 8655.68 & 7419.03 & 6333.6 & 9651.13 & 12936.03 & 9270.66 & 9589.1 & 12888.91 & 11403.29 \\
\hline Schöffen & 9453.33 & 9095.33 & 7185.34 & 9272.84 & 11474.4 & 9119.58 & 9375.93 & 11144.51 & 10909.63 \\
\hline Market development & 9375.64 & 7497.82 & 6496.39 & 7928.8 & 10922.29 & 8302.28 & 6946.69 & 9970.31 & 9812.02 \\
\hline Foreign moneylenders & 13157.44 & 9404.1 & 7866.79 & 9889.95 & 15460.75 & 8868.54 & 11139.86 & 13475.35 & 14124.14 \\
\hline
\end{tabular}




\begin{tabular}{|c|c|c|c|c|c|c|c|c|c|}
\hline Mint & 8392.41 & 6903.18 & 4664.26 & 5100.46 & 6780.66 & 6967.32 & 4136.27 & 6198.45 & 5928.13 \\
\hline Jewish community development & 2847.92 & 2613 & 2127.62 & 2813.08 & 2841.92 & 2230.04 & 2259.28 & 2777.17 & 2135.58 \\
\hline Total previous persecutions & 2399.41 & 1643.06 & 1606.25 & 2161.51 & 2431.14 & 1291.03 & 1870.81 & 2035.09 & 1888.85 \\
\hline Total previous expulsions & 10165.06 & 7553.21 & 6881.59 & 7804.36 & 10783.92 & 8324.77 & 7034.36 & 10961.43 & 10646.45 \\
\hline $1401-1415$ & 8860.06 & 7382.59 & 13556.04 & 7666.63 & 10482.25 & 8178.78 & 6614.01 & 9221.02 & 10494.33 \\
\hline $1416-1430$ & 6273.00 & 5268.7 & 2785.16 & 5012.5 & 7375.19 & 6171.31 & 5025.98 & 6501.9 & 7287.89 \\
\hline $1431-1445$ & 4666.87 & 3760.89 & 2825.79 & 4697.8 & 6564.12 & 5894.15 & 4509.79 & 5667.5 & 6979.2 \\
\hline $1446-1460$ & 4591.6 & 3354.64 & 2754.03 & 4544.35 & 5659.54 & 4213.76 & 4145.83 & 5170.02 & 6179.48 \\
\hline $1461-1475$ & 3746.64 & 2841.82 & 2771.41 & 3429.36 & 4273.74 & 3524.89 & 2917.96 & 3820.16 & 4164.25 \\
\hline $1476-1490$ & 3321.98 & 3072.61 & 2709.99 & 2899.4 & 3775.9 & 3434.08 & 2618.52 & 3485.74 & 3574.21 \\
\hline $1491-1505$ & 3236.62 & 2742.25 & 2638.51 & 2872.86 & 3533.62 & 2722.15 & 2445.51 & 3187.58 & 3455.14 \\
\hline $1506-1520$ & 3156.53 & 2335.23 & 2670.81 & 2623.05 & 3149.78 & 2231.51 & 2275.14 & 2602.93 & 2901.25 \\
\hline Global Intercept & 2449.81 & 2164.68 & 3321.19 & 3051.53 & 3772.08 & 2004.53 & 2866.17 & 3395.84 & 2966.33 \\
\hline Sigma & 1404.25 & 1131.63 & 1065.97 & 1333.72 & 1438.98 & 875.93 & 1221.49 & 1343.96 & 1070.71 \\
\hline
\end{tabular}

Note. For effective sample size values, * indicates $\mathcal{R}>1.01$ and ** indicates $\mathcal{R}>1.05$. 
Table C3. Model Statistics: Exact $K$-fold cross-validation

\begin{tabular}{lllllll}
\hline & $(1)$ & $(2)$ & $(3)$ & $(4)$ & $(5)$ & $(6)$ \\
\hline ELPD & -643.21 & -643.76 & -627.28 & -634.61 & -633.88 & -631.27 \\
ELPD SE & 53.85 & 53.93 & 52.72 & 53.01 & 52.99 & 52.78 \\
\hline
\end{tabular}


Table C4. Full Model Results

\begin{tabular}{|c|c|c|c|c|c|c|c|c|c|c|c|c|}
\hline & (1) & & (2) & & (3) & & (4) & & $(5)$ & & (6) & \\
\hline & Mean & SD & Mean & SD & Mean & $\mathrm{SD}$ & Mean & $\mathrm{SD}$ & Mean & SD & Mean & $\mathrm{SD}$ \\
\hline Dif1 & -0.68 & 0.32 & 0.18 & 0.50 & -0.35 & 1.48 & & & & & & \\
\hline Dif2 (any) & & & -1.00 & 0.48 & & & & & & & -1.3 & 0.35 \\
\hline Dif2 (episcopal) & & & & & & & & & -0.82 & 0.4 & & \\
\hline Dif2 (free/imperial) & & & & & & & & & -0.49 & 0.63 & & \\
\hline Dif3 (episcopal) & & & & & & & -1.33 & 2.91 & -1.02 & 2.91 & & \\
\hline Dif3 (free/imperial) & & & & & & & 0.2 & 0.36 & 0.86 & 0.47 & 0.5 & 0.36 \\
\hline $\begin{array}{l}\text { Dif3 (episc.) } \\
\text { episc. }\end{array}$ & & & & & & & 0.71 & 2.93 & 0.85 & 2.92 & & \\
\hline $\begin{array}{l}\text { Dif3 (free/imp.) * } \\
\text { free/imp. }\end{array}$ & & & & & & & 0.11 & 0.41 & 0.31 & 0.44 & 0.26 & 0.41 \\
\hline $\begin{array}{l}\text { After Council of } \\
\text { Constance }\end{array}$ & & & & & 3.23 & 1.37 & & & & & & \\
\hline $\begin{array}{l}\text { Dif } 1 * \text { After } \\
\text { Constance }\end{array}$ & & & & & -0.72 & 1.49 & & & & & & \\
\hline $\mathrm{Km}$ to Constance & & & & & -1.08 & 0.49 & -1.07 & 0.43 & -1.1 & 0.43 & & \\
\hline $\begin{array}{l}\text { Count of Travel } \\
\text { Routes }\end{array}$ & & & -0.30 & 0.35 & & & & & & & & \\
\hline $\begin{array}{l}\text { Total Prior } \\
\text { Alliance Treaties }\end{array}$ & 0.34 & 0.32 & 0.32 & 0.30 & & & & & & & & \\
\hline Bishop & -0.37 & 0.64 & -0.34 & 0.63 & -0.19 & 0.68 & & & & & & \\
\hline Archbishop & -0.29 & 0.65 & -0.12 & 0.65 & -0.09 & 0.68 & & & & & & \\
\hline Episcopal & & & & & & & 0.51 & 0.88 & 0.5 & 0.88 & -0.3 & 0.51 \\
\hline Free & 0.82 & 0.58 & 0.82 & 0.55 & 0.58 & 0.60 & & & & & & \\
\hline Imperial & -0.15 & 0.74 & -0.12 & 0.72 & 0.07 & 0.75 & & & & & & \\
\hline Free or imperial & & & & & & & 0.06 & 0.62 & -0.12 & 0.63 & 0.11 & 0.59 \\
\hline
\end{tabular}




\begin{tabular}{|c|c|c|c|c|c|c|c|c|c|c|c|c|}
\hline Prince & -0.16 & 0.5 & -0.14 & 0.48 & -0.1 & 0.52 & -0.12 & 0.51 & -0.13 & 0.52 & -0.18 & 0.49 \\
\hline $\begin{array}{l}\text { Count of dominion } \\
\text { parties }\end{array}$ & -0.13 & 0.44 & -0.12 & 0.43 & -0.24 & 0.47 & -0.22 & 0.42 & -0.24 & 0.42 & -0.17 & 0.39 \\
\hline Schöffen & -1.36 & 0.71 & -1.3 & 0.67 & -1.32 & 0.73 & -1.19 & 0.66 & -1.2 & 0.68 & -1.14 & 0.64 \\
\hline $\begin{array}{l}\text { Market } \\
\text { development }\end{array}$ & 0.35 & 0.36 & 0.32 & 0.34 & 0.36 & 0.38 & 0.32 & 0.35 & 0.31 & 0.35 & 0.28 & 0.33 \\
\hline $\begin{array}{l}\text { Foreign } \\
\text { moneylenders }\end{array}$ & 1.47 & 0.64 & 1.54 & 0.62 & 1.72 & 0.7 & 1.55 & 0.62 & 1.55 & 0.63 & 1.42 & 0.59 \\
\hline Mint & 1.06 & 0.44 & 0.95 & 0.41 & 1.64 & 0.51 & 1.51 & 0.46 & 1.51 & 0.48 & 1.01 & 0.4 \\
\hline $\begin{array}{l}\text { Jewish community } \\
\text { development }\end{array}$ & 1.59 & 0.43 & 1.53 & 0.4 & 1.56 & 0.47 & 1.34 & 0.43 & 1.38 & 0.44 & 1.46 & 0.4 \\
\hline $\begin{array}{l}\text { Total previous } \\
\text { persecutions }\end{array}$ & -0.3 & 0.21 & -0.22 & 0.21 & -0.34 & 0.23 & -0.26 & 0.21 & -0.27 & 0.22 & -0.21 & 0.21 \\
\hline $\begin{array}{l}\text { Total previous } \\
\text { expulsions }\end{array}$ & 0.53 & 0.31 & 0.58 & 0.3 & 0.82 & 0.34 & 0.78 & 0.3 & 0.78 & 0.31 & 0.63 & 0.29 \\
\hline $1401-1415$ & -0.17 & 0.67 & -0.21 & 0.67 & 0.55 & 0.81 & -0.11 & 0.67 & -0.13 & 0.68 & -0.19 & 0.68 \\
\hline $1416-1430$ & 1.36 & 0.52 & 1.36 & 0.52 & -1.11 & 0.93 & 1.38 & 0.53 & 1.27 & 0.54 & 1.34 & 0.52 \\
\hline $1431-1445$ & 1.92 & 0.6 & 1.55 & 0.62 & -0.42 & 0.92 & 1.28 & 0.59 & 1.14 & 0.59 & 1.24 & 0.58 \\
\hline $1446-1460$ & 1.97 & 0.61 & 1.52 & 0.63 & -0.39 & 0.91 & 1.62 & 0.59 & 1.52 & 0.6 & 1.56 & 0.58 \\
\hline $1461-1475$ & 2.62 & 0.63 & 2.22 & 0.63 & 0.32 & 0.9 & 2.27 & 0.6 & 2.23 & 0.61 & 2.41 & 0.59 \\
\hline $1476-1490$ & 3.28 & 0.66 & 3.32 & 0.63 & 1.06 & 0.91 & 2.61 & 0.62 & 2.76 & 0.62 & 3.4 & 0.62 \\
\hline $1491-1505$ & 3.08 & 0.66 & 2.82 & 0.64 & 0.81 & 0.91 & 2.75 & 0.64 & 2.75 & 0.65 & 2.97 & 0.62 \\
\hline $1506-1520$ & 3.83 & 0.75 & 3.26 & 0.75 & 1.69 & 0.97 & 3.14 & 0.7 & 3.03 & 0.71 & 3.21 & 0.68 \\
\hline Global Intercept & -10.02 & 0.93 & -9.65 & 0.88 & -11.28 & 1.45 & -10.03 & 1.13 & -10.1 & 1.14 & -9.52 & 0.86 \\
\hline $\begin{array}{l}\text { Nested random } \\
\text { effects }\end{array}$ & Yes & & Yes & & Yes & & Yes & & Yes & & Yes & \\
\hline Sigma & 3.79 & 1.72 & 2.88 & 1.45 & 4.28 & 2.01 & 3.1 & 1.57 & 3.34 & 1.67 & 2.77 & 1.41 \\
\hline Log-posterior & \multicolumn{2}{|l|}{-2976.16} & \multicolumn{2}{|c|}{-2985.73} & \multicolumn{2}{|c|}{-2960.65} & \multicolumn{2}{|c|}{-2983.26} & \multicolumn{2}{|c|}{-2980.67} & \multicolumn{2}{|c|}{-2980.04} \\
\hline
\end{tabular}




\section{REFERENCES}

Anderson, Warren, Noel D. Johnson, and Mark Koyama. 2017. "Jewish Persecutions and Weather Shocks: 1100-1800.” The Economic Journal 127(602):924-58. doi: 10.1111/ecoj.12331.

Behringer, Wolfgang. 1995. "Weather, Hunger and Fear: Origins of the European Witch-Hunts in Climate, Society and Mentality." German History 13(1):1-25. doi: 10.1093/gh/13.1.1.

Behringer, Wolfgang. 1999. "Climatic Change and Witch-Hunting: The Impact of the Little Ice Age on Mentalities." Climatic Change 43(1):335-51. doi: 10.1023/A:1005554519604.

Betancourt, Michael. 2017. "How the Shape of a Weakly Informative Prior Affects Inferences." Retrieved September 29, 2018 (http://mc-stan.org/users/documentation/casestudies/weakly_informative_shapes.html).

Bossak, Brian H., and Mark R. Welford. 2015. "Spatio-Temporal Characteristics of the Medieval Black Death." Pp. 71-84 in Spatial Analysis in Health Geography, edited by P. Kanaroglu, E. Delmelle, and A. Páez. New York: Routledge.

Distler, Eva-Marie. 2006. Städtebünde im deutschen Spätmittelalter: eine rechtshistorische Untersuchung zu Begriff, Verfassung und Funktion. Frankfurt am Main: Klostermann.

Gelman, Andrew, Aleks Jakulin, Maria Grazia Pittau, and Yu Sung Su. 2008. "A Weakly Informative Default Prior Distribution for Logistic and Other Regression Models." Annals of Applied Statistics 2(4):1360-83. doi: 10.1214/08-AOAS191.

Guiot, Joel, Christophe Corona, and ESCARCEL Members. 2010. “Growing Season Temperatures in Europe and Climate Forcings over the Past 1400 Years." PLoS ONE 5(4):e9972. doi: 10.1371/journal.pone.0009972.

Haverkamp, Alfred. 1995. "The Jewish Quarters in German Towns during the Late Middle Ages." Pp. 13-28 in In and Out of the Ghetto: Jewish-Gentile Relations in Late Medieval and Early Modern Germany, edited by R. P. Hsia and H. Lehmann. New York: Cambridge University Press.

Haverkamp, Alfred, ed. 2002. Geschichte der Juden im Mittelalter von der Nordsee bis zu den Südalpen: Kommentiertes Kartenwerk, 1: Kommentarband; 2: Ortskatalog; 3: Karten. Vols. 1-3. Hannover: Hahnsche Buchhandlung.

Kelly, Morgan. 2019. The Standard Errors of Persistence. WP19/13. University College Dublin.

Keyser, Erich, and Heinz Stoob, eds. 1939. Deutsches Städtebuch, Handbuch städtischer Geschichte. Stuttgart: Kohlhammer.

Landrum, Laura, Bette L. Otto-Bliesner, Eugene R. Wahl, Andrew Conley, Peter J. Lawrence, Nan Rosenbloom, and Haiyan Teng. 2012. "Last Millennium Climate and Its Variability in CCSM4.” Journal of Climate 26(4):1085-1111. doi: 10.1175/JCLI-D-11-00326.1. 
McElreath, Richard. 2016. Statistical Rethinking: A Bayesian Course with Examples in R and Stan. Boca Raton, FL: Chapman \& Hall/CRC Press.

Oster, Emily. 2004. "Witchcraft, Weather and Economic Growth in Renaissance Europe." The Journal of Economic Perspectives 18(1):215-28.

Stan Development Team. 2018a. "Rstanarm: Bayesian Applied Regression Modeling via Stan."

Stan Development Team. 2018b. "Stan Development Repository: Prior Choice Recommendations.” Retrieved September 29, 2018 (https://github.com/standev/stan/wiki/Prior-Choice-Recommendations).

Tiefelsdorf, Michael. 2000. Modelling Spatial Processes: The Identification and Analysis of Spatial Relationships in Regression Residuals by Means of Moran's I. Berlin; New York: Springer-Verlag.

Tyers, Matt. 2017. "Riverdist: River Network Distance Computation and Applications."

Vehtari, Aki, Jonah Gabry, Yuling Yao, and Andrew Gelman. 2018. "Loo: Efficient Leave-OneOut Cross-Validation and WAIC for Bayesian Models."

Vehtari, Aki, Andrew Gelman, and Jonah Gabry. 2017. "Practical Bayesian Model Evaluation Using Leave-One-out Cross-Validation and WAIC." Statistics and Computing 27(5):1413-32. doi: 10.1007/s11222-016-9696-4. 